\title{
Thermokarst lake inception and development in syngenetic ice-wedge polygon terrain during a cooling climatic trend, Bylot Island (Nunavut), eastern Canadian Arctic
}

\author{
Frédéric Bouchard $^{1,2,3,6}$, Daniel Fortier ${ }^{2,3}$, Michel Paquette ${ }^{4}$, Vincent Boucher ${ }^{5}$, Reinhard Pienitz ${ }^{2,5}$, and \\ Isabelle Laurion ${ }^{2,6}$ \\ ${ }^{1}$ Géosciences Paris Sud (GEOPS), Université Paris-Saclay, Orsay, France \\ ${ }^{2}$ Centre d'études nordiques (CEN), Université Laval, Québec, Canada \\ ${ }^{3}$ Département de géographie, Université de Montréal, Montréal, Canada \\ ${ }^{4}$ Department of Geography and Planning, Queen's University, Kingston, Canada \\ ${ }^{5}$ Département de géographie, Université Laval, Québec, Canada \\ ${ }^{6}$ Centre Eau Terre Environnement, Institut national de la recherche scientifique (INRS-ETE), Québec, Canada
}

Correspondence: Frédéric Bouchard (frederic.bouchard@u-psud.fr)

Received: 23 October 2019 - Discussion started: 30 October 2019

Revised: 19 June 2020 - Accepted: 24 June 2020 - Published: 20 August 2020

\begin{abstract}
Thermokarst lakes are widespread and diverse across permafrost regions, and they are considered significant contributors to global greenhouse gas emissions. Paleoenvironmental reconstructions documenting the inception and development of these ecologically important water bodies are generally limited to Pleistocene-age permafrost deposits of Siberia, Alaska, and the western Canadian Arctic. Here we present the gradual transition from syngenetic ice-wedge polygon terrain to a thermokarst lake in Holocene sediments of the eastern Canadian Arctic. We combine geomorphological surveys with paleolimnological reconstructions from sediment cores in an effort to characterize local landscape evolution from a terrestrial to freshwater environment. Located on an iceand organic-rich polygonal terrace, the studied lake is now evolving through active thermokarst, as revealed by subsiding and eroding shores, and was likely created by water pooling within a pre-existing topographic depression. Organic sedimentation in the valley started during the midHolocene, as documented by the oldest organic debris found at the base of one sediment core and dated at $4.8 \mathrm{kyrBP}$. Local sedimentation dynamics were initially controlled by fluctuations in wind activity, local moisture, and vegetation growth and accumulation, as shown by alternating loess (silt) and peat layers. Fossil diatom assemblages were
\end{abstract}

likewise influenced by local hydro-climatic conditions and reflect a broad range of substrates available in the past (both terrestrial and aquatic). Such conditions likely prevailed until $2000 \mathrm{BP}$, when peat accumulation stopped as water ponded the surface of degrading ice-wedge polygons, and the basin progressively developed into a thermokarst lake. Interestingly, this happened in the middle of the Neoglacial cooling period, likely under colder-than-present but wetter-than-average conditions. Thereafter, the lake continued to develop as evidenced by the dominance of aquatic (both benthic and planktonic) diatom taxa in organic-rich lacustrine muds. Based on these interpretations, we present a four-stage conceptual model of thermokarst lake development during the late Holocene, including some potential future trajectories. Such a model could be applied to other formerly glaciated syngenetic permafrost landscapes.

\section{Introduction}

Lakes are extremely abundant across the circumpolar regions, with millions of water bodies spread over an estimated total surface area ranging from $\sim 1.4 \times 10^{6}$ to $1.8 \times 10^{6} \mathrm{~km}^{2}$ (Muster et al., 2017; Paltan et al., 2015; 
Verpoorter et al., 2014). The vast majority of these aquatic systems is located in permafrost environments, especially in lowland regions with moderate to high excess ground-ice content (typically $>30 \%$ in volume) and a thick sediment cover (Grosse et al., 2013; Smith et al., 2007). Recent highresolution mapping efforts reported significant variability in water body size distributions across permafrost regions (Muster et al., 2017). Thermokarst (thaw) lakes occur mainly in ice-rich permafrost regions, where ground-ice melting can result in localized ground surface subsidence, water accumulation and self-maintained lake expansion (van Everdingen, 1998). These lakes vary greatly in morphology, depth $(<1 \mathrm{~m}$ to several meters deep in most cases) and area (from a few meters across to several square kilometers), depending on ground-ice content and distribution, lake age, hydro-climatic conditions, and local topography (e.g., Côté and Burn, 2002; Hopkins, 1949; Pienitz et al., 2008). Some of the lakes located in unglaciated ice-rich (Yedoma) terrains of Siberia, Alaska and western Canada started to develop in the late Pleistocene and form a separate lake category, up to several tens of meters deep (e.g., Farquharson et al., 2016; Lenz et al., 2016). However, the majority of thermokarst lakes across the Arctic are shallow (a few meters), and most of them were formed in formerly glaciated terrains during the Holocene (Grosse et al., 2013; Smith et al., 2007).

Thermokarst lake evolution involves a remarkably diverse suite of hydro-climatic, geomorphological and ecological processes (Bouchard et al., 2017; Grosse et al., 2013). Although modern thermokarst processes and landforms may involve anthropogenic causes, thermokarst development during the Holocene can be associated with three main drivers: increased air and ground temperatures, ground disturbances (through fluvial, thermal or ecological mechanisms, e.g., slumps or fires), and snow accumulation (e.g., Anderson et al., 2019; French, 2017). In the third case, the insulating capacity of a thick snow cover can substantially prevent ground cooling during the winter, resulting in significantly higher ground temperatures (near $0^{\circ} \mathrm{C}$ ) and hence promoting localized or widespread permafrost thawing the following summer (Frauenfeld et al., 2004; Morse et al., 2012). When lake depth exceeds the maximum thickness of winter ice cover, bottom water stays unfrozen throughout the year and mean annual lake-bottom temperature remains above $0{ }^{\circ} \mathrm{C}$, resulting in the formation of a talik (thaw bulb) underneath the lake (Burn, 2002). Once initiated, thermokarst lakes in continuous permafrost tend to develop laterally: first by the coalescence of polygonal and/or ice-wedge trough pools overlying melting icewedge networks (Czudek and Demek, 1970; Mackay, 2000; French, 2017) and then by thermal and mechanical shoreline erosional processes, such as wave-induced erosional niche development or mass wasting through thaw slumping and block failures (Kokelj and Jorgenson, 2013). Ultimately, and depending on local landscape conditions (e.g., soil type, vegetation cover, topography), thermokarst lake development generally ends with one or more of the following: rapid drainage resulting from shoreline breaching, either during higher-than-average lake-level episodes (e.g., Jones and Arp, 2015; Lantz and Turner, 2015; Mackay and Burn, 2002; Turner et al., 2010) or due to ice-wedge melting and thermal erosion gullying (e.g., Fortier et al., 2007; Godin and Fortier, 2012); lake-level drawdown due to factors that lead to increased evaporation (Bouchard et al., 2013a; Riordan et al., 2006); subsurface drainage (groundwater infiltration) through an open talik (Yoshikawa and Hinzman, 2003); or terrestrialization via rapid peat accumulation and lake infilling (Payette et al., 2004; Roach et al., 2011).

Thermokarst lakes play a key role in the global carbon cycle (e.g., Cole et al., 1994; Serikova et al., 2019; Wik et al., 2016), because they form in areas where organic carbon is stored in frozen soils (Hugelius et al., 2014; Schuur et al., 2015). Consequently, they are biogeochemical hotspots through their release of substantial amounts of carbon dioxide $\left(\mathrm{CO}_{2}\right)$ and methane $\left(\mathrm{CH}_{4}\right)$ to the atmosphere (e.g., Abnizova et al., 2012; Laurion et al., 2010; Matveev et al., 2018; Walter et al., 2007). A fundamental aspect of thermokarst lakes is the age (millennium old vs. modern) of the carbon stored in the frozen soil and released by thermokarst ecosystems, which is linked to the potential of a thermokarst lake to generate a positive feedback on climate (Elder et al., 2018; Mann et al., 2015; Vonk et al., 2013). Carbon older than $\sim 500$ to 1000 years can be considered "in excess" in the system, thus representing a net atmospheric contribution from a formerly stable reservoir (Archer et al., 2009). Work conducted in the eastern Canadian Arctic, in eastern Siberia and in Alaska has shown that radiocarbon age can indeed vary by several orders of magnitude over a small area, depending on water body properties (Bouchard et al., 2015a; Dean et al., 2020; Elder et al., 2018). Yet, the majority of studies focusing on the age and sources of $\mathrm{CO}_{2}$ and $\mathrm{CH}_{4}$ released by thermokarst lakes come from Yedoma regions, which represent a small fraction $(\sim 4 \%-6 \%)$ of total permafrost areas $\left(\sim 1.0 \times 10^{6}-1.4 \times 10^{6} \mathrm{~km}^{2}\right.$ out of $23 \times$ $10^{6} \mathrm{~km}^{2}$ in total, e.g., Strauss et al., 2017). Lakes formed in formerly glaciated terrains are widespread across the Arctic and can contribute significantly to global greenhouse gas emissions (Smith et al., 2007; Wik et al., 2016).

Here we document the development of a thermokarst lake in a tundra valley of the eastern Canadian Arctic (Bylot Island, Nunavut, Canada) during the Holocene. We test the hypothesis that this lake developed following local landscape dynamics and not solely because of increased temperatures. The lake is located within an ice- and organic-rich syngenetic permafrost environment (Fortier and Allard, 2004). It thus serves as an interesting case study of a landscape that is under-represented in the thermokarst literature. We combine high-resolution lake mapping, geomorphological observations and paleolimnological reconstructions (both litho- and biostratigraphy) in an effort to (1) document the inception and evolution of a thermokarst lake in syngenetic 
ice-wedge polygon terrain, (2) characterize the transition from terrestrial to aquatic conditions in a tundra valley setting, and (3) present a conceptual model of thermokarst development in syngenetic ice-wedge polygon terrain during a cool climate episode of the late Holocene.

\section{Study site}

Bylot Island (Nunavut) is located in the eastern Canadian Arctic, within the continuous permafrost zone (Fig. 1a). Most of the island is mountainous, and several glaciers spread from its center to peripheral lowland areas (Fig. 1b). The valleys of these glaciers were shaped during the successive Pleistocene glaciations (Klassen, 1993), and since the Holocene, they developed into highly dynamic biogeosystems rich in vegetation, ground ice, peat and aquatic environments (Allard, 1996; Fortier and Allard, 2004). The prevailing climate is polar with a slight marine influence. Based on the 1980-2010 climate normals from the closest meteorological station located $\sim 80 \mathrm{~km}$ away in the village of Mittimatalik (Pond Inlet) on Baffin Island $\left(72^{\circ} 41^{\prime} \mathrm{N}, 77^{\circ} 58^{\prime} \mathrm{W}\right)$, the mean annual air temperature is $-14.6^{\circ} \mathrm{C}$, with average daily temperatures ranging from $-33.4^{\circ} \mathrm{C}$ in January to $6.6^{\circ} \mathrm{C}$ in July, and a total precipitation of $189 \mathrm{~mm}$, of which $91 \mathrm{~mm}$ fall as rain between June and September (Environment Canada, 2019). Thawing and freezing degree-days are around 475 and 5735 , respectively. Winter, defined here as when continuous daily mean air temperature remains $<0{ }^{\circ} \mathrm{C}$, lasts from early September to mid-June for an average total of $283 \mathrm{~d} \mathrm{yr}^{-1}$. A station operated since 2004 by the Centre for Northern Studies (CEN) at the study site provides similar climate data (CEN, 2018).

The study site $\left(73^{\circ} 09^{\prime} \mathrm{N}, 79^{\circ} 58^{\prime} \mathrm{W}\right)$ is located in the valley locally named Qarlikturvik, which has a NE-SW orientation and a surface area of $\sim 65 \mathrm{~km}^{2}(\sim 15 \mathrm{~km}$ long $\times 4-5 \mathrm{~km}$ wide) (Fig. 1c). A terminal moraine, located roughly halfway between the actual glacier (C-79) front and the seashore and sitting on marine clay, was ${ }^{14} \mathrm{C}$ dated to $\sim 9.8 \mathrm{kyr} \mathrm{BP}$ (Allard, 1996). Holocene glacial retreat was accompanied by a marine transgression phase, which ended around $6 \mathrm{kyr} \mathrm{BP}$ (Allard, 1996). Like the majority of glaciers on Bylot Island, the C-79 glacier has recently been retreating from 0.9 to $1.8 \mathrm{~km}$ up the valley since the early 20th century, with most retreat occurring between 1958/1961 and 2001 (Dowdeswell et al., 2007). Marine clays deposited during the postglacial transgression phase were subsequently covered by glaciofluvial sands and gravels (Fortier and Allard, 2004). Today, a braided river flows through the glacio-fluvial outwash plain, carrying sediments towards a delta aggrading in Navy Board Inlet. This outwash plain is bordered on both sides by a 3 to $5 \mathrm{~m}$ thick terrace, crisscrossed by networks of tundra polygons associated with the formation of syngenetic ice wedges. Along the southern bank of the river, the upper portion of this terrace is composed of alternating mineral (wind-blown sand and silt) and organic (peat) material, which started to accumulate over glacio-fluvial sands and gravels at least 3700 years ago (Fortier and Allard, 2004). These peaty loess deposits in which permafrost aggrades syngenetically are typically ice rich, and their organic matter content can reach over $50 \%$. The active layer depth in such deposits generally ranges between 40 and $80 \mathrm{~cm}$ (down to $1 \mathrm{~m}$ in sandy and gravelly material), and the maximum depth of permafrost on Bylot Island has been estimated to be over $400 \mathrm{~m}$ (Allard et al., 2016; Smith and Burgess, 2000).

The sampled lake, informally named Gull Lake (maximum depth $\sim 4.2 \mathrm{~m}$ ), is located within the lake- and pond-rich polygonal terrace, near the terminal moraine (Fig. 1c). Limnological observations conducted during the ice-free season indicate relatively low concentrations of dissolved organic carbon (DOC), nutrients and ions in Gull Lake compared to the surrounding ice-wedge troughs and coalescent polygonal ponds, as well as a thermally homogenous and well-oxygenated water column. However, dissolved oxygen concentrations decrease rapidly under the winter ice cover and at the bottom of the lake, near the watersediment interface (Bouchard et al., 2015a). Greenhouse gas (GHG) sampling and dating showed that this lake is a relatively small but spatially variable source of dissolved and ebullition GHG, with millennium-age methane released in its center (up to $3.5 \mathrm{kyr} \mathrm{BP}$ ) and peripheral shallow zones (up to $2.8 \mathrm{kyrBP}$ ). The age of methane emitted from the central zone is almost corresponding to the maximum age of syngenetic organic sedimentation in the valley $(3.7 \mathrm{kyr} \mathrm{BP})$ (Bouchard et al., 2015a; Fortier and Allard, 2004).

\section{Materials and methods}

\subsection{Lake watershed and geomorphology}

A portable sonar system, equipped with an internal GPS antenna (Humminbird model 859XD) and mounted on a small Zodiac, was used to map the lake bottom in July 2014 (as in Bouchard et al., 2015b). Lake-depth signals were continuously recorded along regularly spaced (20$25 \mathrm{~m}$ apart) navigation lines, mainly of SW-NE and SENW orientations. Depth data were interpolated between navigation lines using the compatible software (AutoChart) to produce a georeferenced 3-D bathymetric map. The acquired data were also used to calibrate and extrapolate lake-bottom depths inferred from ground-penetrating radar (GPR) mapping conducted the following year.

Ground-penetrating radar (GPR) surveying on lake ice cover allows for an accurate description of lake-bottom topography (Moorman, 2001; Paquette et al., 2015; You et al., 2017). Three GPR survey lines crossing the lake were done in May 2015 (Fig. 2) using a sleigh-dragged Sensors and Software PulseEkko GPR and $50 \mathrm{MHz}$ antennas. GPR line processing was performed using Ekko project software 

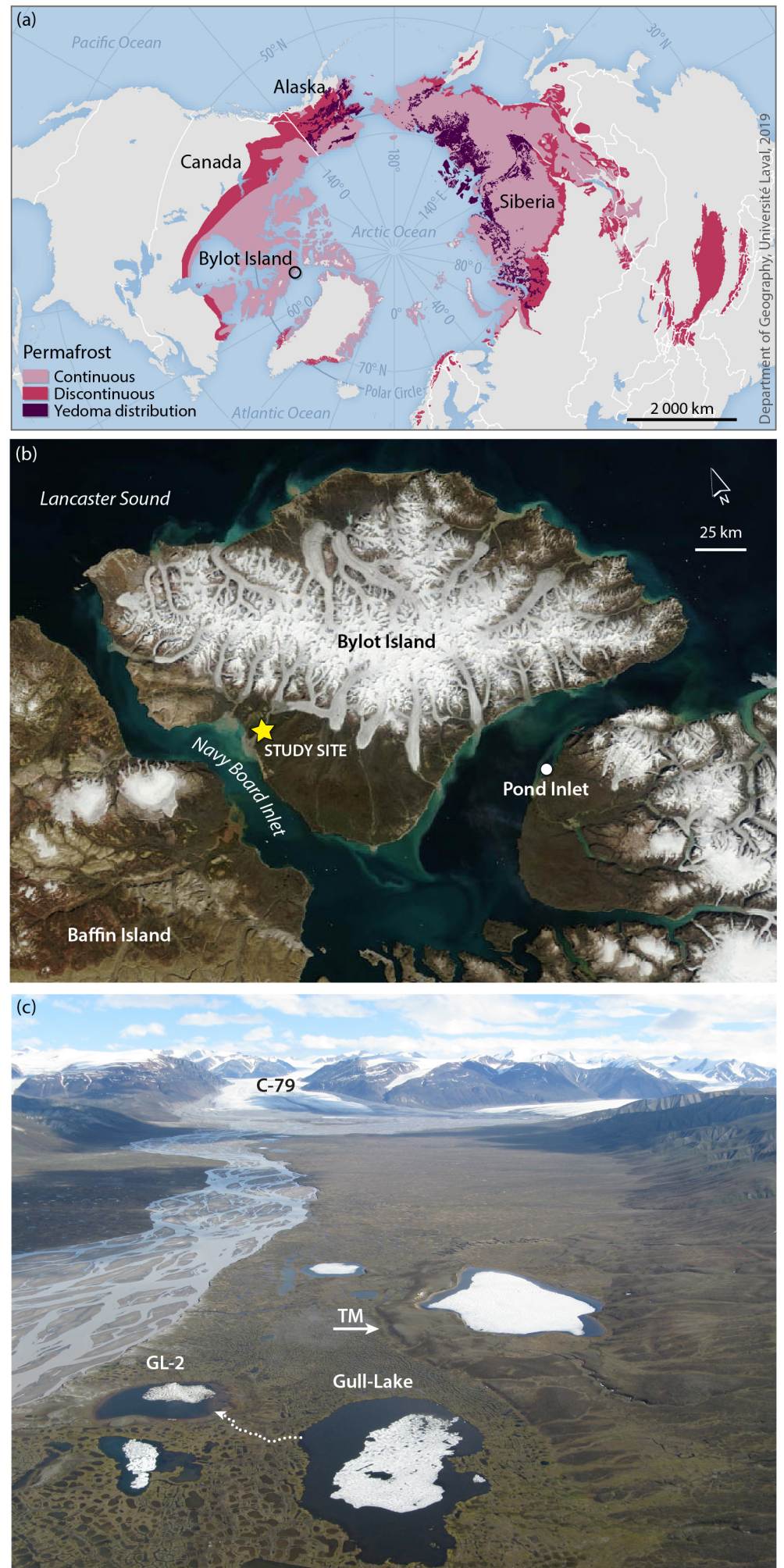

Figure 1. Study area location and context. (a) Location of Bylot Island (Nunavut), Canada, within the continuous permafrost zone (source: Brown et al., 1998). Pleistocene ice-rich permafrost distribution in nonglaciated regions of Siberia and Alaska (Yedoma) is also shown (source: Strauss et al., 2017). (b) Location of the study site on the southwestern lowlands of Bylot Island (satellite photo: Terra-MODIS, 22 July 2012). (c) Location of Gull Lake, in Qarlikturvik valley (glacier C-79 in the background). An early Holocene terminal moraine (TM) and a small outlet, draining towards "Gull Lake 2" (GL-2) and the proglacial river, are also shown. 


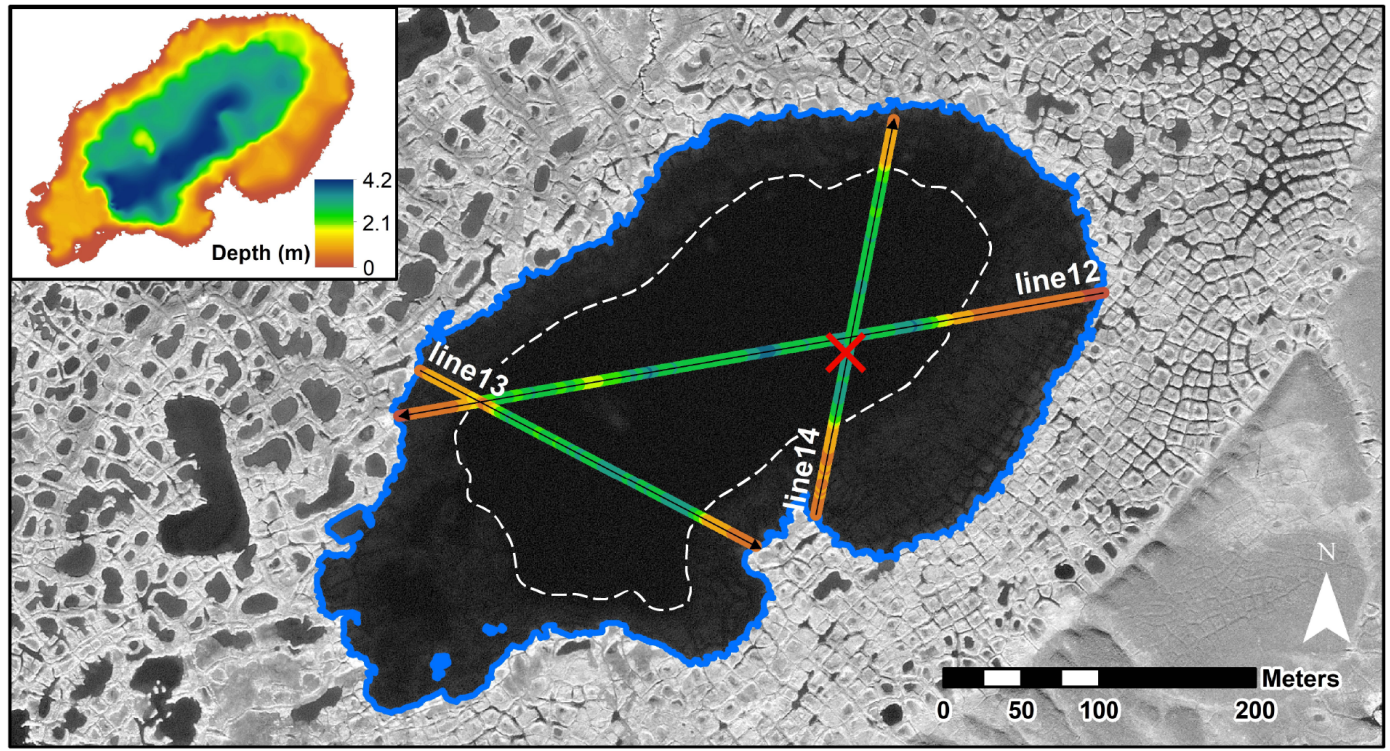

Figure 2. Bathymetry and GPR survey lines conducted on Gull Lake. Sediment coring location is shown (red "x"). GPR line cross sections $(12,13,14)$ are shown in Fig. 3. The lake limit is delineated by a blue polygon. The central basin is deeper and surrounded by a shallow platform where degraded ice-wedge polygons are visible. The boundary between the central basin and the shallow platform is shown by the dashed white line. Satellite image: GeoEye-1, 18 July 2010.

and included dewow, a low-pass temporal filter to diminish background noise and a background average subtraction to remove the overwhelming ice and water boundary signal. The base of the ice cover and lake-bottom depth were manually identified and corresponded well to the dielectric properties of ice and water. Signal travel velocities of 0.06 and $0.13 \mathrm{~m} \mathrm{~ns}^{-1}$ were used for unfrozen and frozen ground, respectively, and GPR vertical signal resolution (no pulse overlap) is approximately $1 \mathrm{~m}$ but slightly lower in ice and frozen ground than in water. There are important limiting factors affecting GPR signal at the bottom of a lake: the strong reflectivity of the ice-water interface $(-0.67)$ and of the water-sediment interface $(+0.5)$, as well as the high permittivity of water (80), quickly diminish the signal intensity.

Temperature in surface sediments (near bottom waters) was monitored over a full year (July 2014 to July 2015) at $1 \mathrm{~h}$ intervals using thermal sensors (Hobo U12; accuracy $\pm 0.25^{\circ} \mathrm{C}$; resolution $0.025^{\circ} \mathrm{C}$; operation range -40 to $125^{\circ} \mathrm{C}$ ) deployed at two sites: (1) near the lake center in deeper waters ( $>4 \mathrm{~m}$ ) and (2) in the shallow peripheral zone (see Sect. 4.1 below).

\subsection{Sediment core sampling and logging}

Sediment cores were collected from the same location (Fig. 2) during two consecutive years: (1) a shorter core $(54 \mathrm{~cm})$ from a boat during the ice-free season of 2014 (July) and (2) a longer core $(109 \mathrm{~cm})$ from the ice cover in spring 2015 (June). The coring site location (> $4 \mathrm{~m}$ water depth) was located in 2014 and 2015 using the bathymetric data from the sonar and GPR surveys (Bouchard et al., 2015b). Each core was retrieved using a handheld percussion corer equipped with a $7 \mathrm{~cm}$ diameter clear polycarbonate tube (Aquatic Research Instruments). Coring was stopped when the tube would not penetrate further into the sediments (coarse sands and gravels). The 2014 core was subsampled in the field immediately after retrieval at $1 \mathrm{~cm}$ intervals, and the subsamples were transferred into polyethylene bags and brought back to the laboratory where they were kept in the dark at $4{ }^{\circ} \mathrm{C}$. For the 2015 core, water from above the sediment surface was removed immediately after retrieval in order to minimize the mixing of the water-sediment interface (Bouchard et al., 2011). The core was then stored vertically at nonfreezing conditions for at least $48 \mathrm{~h}$, allowing the upper sediments to slowly consolidate by dewatering, after which the supernatant was removed. It was finally sealed with foam blocks to minimize potential disturbances during subsequent transport, brought back to the laboratory and stored in the dark at $4{ }^{\circ} \mathrm{C}$ for further analyses.

The 2014 core was visually examined in the field before and during subsampling to identify general stratigraphic units, such as gyttja (organic-rich lacustrine mud), peat, silt and sand, whereas the 2015 core was described with more detail in the laboratory. First, a nondestructive computed tomographic scan was performed to visualize internal sedimentary structures and infer sediment density (Supplement S1) (Calmels and Allard, 2004). This core was then cut into halves along its longitudinal axis with a rotating saw. One half was covered with a plastic film 
to minimize surface oxidation and desiccation and archived in the dark at $4^{\circ} \mathrm{C}$, and the other half was used for stratigraphic descriptions. Subsampling was then performed on the working half at $1 \mathrm{~cm}$ intervals, and the subsamples were freeze-dried (at least $48 \mathrm{~h}$, depending on water content) and transferred into polyethylene bags for further analyses.

\subsection{Lithological and chronological analyses}

Sediment subsamples from the 2014 and 2015 cores were used to perform physical and chronological analyses. About $0.5 \mathrm{~g}$ of dry sediment was extracted to perform loss-onignition (LOI) measurements by a subsequent combustion at $550{ }^{\circ} \mathrm{C}$ for $4 \mathrm{~h}$ (Heiri et al., 2001). Organic matter content (LOI) and wet and dry sediment mass measurements were used to determine the sediment dry bulk density and to correlate both cores, in addition to visual descriptions. Supplementary subsamples were used to perform grain-size distribution analysis by sieving material coarser than $62.5 \mu \mathrm{m}$ (i.e., sand and gravel) (ASTM, 2004) and using hydrometry for fine sediments (i.e., silt and clay) (ASTM, 2017).

Bulk sediment samples and, when present, fossil organic or wood fragments were carefully extracted and dried in glass bottles at $105^{\circ} \mathrm{C}$ (Björck and Wohlfarth, 2001). Samples were pretreated $(\mathrm{HCl}, \mathrm{NaOH}, \mathrm{HCl})$ and combusted to $\mathrm{CO}_{2}$ at the Radiocarbon Dating Laboratory (Université Laval, Québec, QC, Canada) and ${ }^{14} \mathrm{C}$ dated by accelerator mass spectrometry (AMS) at Keck Carbon Cycle AMS Facility (University of California, Irvine, CA, USA). Radiocarbon dates were reported using Libby's half-life (5568 yr), corrected for natural fractionation $\left(\delta^{13} \mathrm{C}=-25 \%\right.$ PDB $)$, and calibrated with the CALIB 7.1 online program (Stuiver et al., 2019) using the IntCal13 calibration data set (Reimer et al., 2013). Supplementary ${ }^{14} \mathrm{C}$ dates available for the surrounding frozen peat deposits, some of them not yet published, were also compiled and added to the dataset (Allard, 1996; Ellis and Rochefort, 2004, 2006; Fortier et al., 2006; 2020).

\subsection{Diatom analysis}

Fossil diatom analysis was conducted at the Aquatic Paleoecology Laboratory of CEN on 60 subsamples from the 2015 core (each centimeter for the top $12 \mathrm{~cm}$ then each $2 \mathrm{~cm}$ towards core bottom) following Bouchard et al. (2013b). Diatom valves were extracted from $\sim 50 \mathrm{mg}$ samples using acid $\left(\mathrm{H}_{2} \mathrm{SO}_{4}-\mathrm{HNO}_{3}\right)$ digestion techniques and mounted on microscope slides using Naphrax, a highly refractive resin (Battarbee et al., 2001). For each subsample, an average of 400 diatom valves were counted along transects using a Leica DMRX light microscope. Identification was carried out to the lowest taxonomic level possible (i.e., species, variety or morphotype) at $1000 \times$ magnification. Taxonomic identification mainly followed Antoniades et al. (2008, 2009), Fallu et al. (2000), Krammer (2000,
2002), Krammer and Lange-Bertalot (1986, 1988, 1991a, b), Lavoie et al. (2008) and Zimmermann et al. (2010). The complete diatom dataset is available as an open-access dataset (Pienitz et al., 2019). Diatom taxa representing at least $1 \%$ (relative abundance) in at least one sample were displayed on abundance diagrams using the $\mathrm{C} 2$ software (Juggins, 2014). Photos of most of these taxa were taken with a Leica DFC490 camera (mounted on the microscope) and were used to prepare plates of the representative taxa (Supplement S2). In the following sections, taxa names are presented as they appeared originally in consulted floras.

\section{Results}

\subsection{Lake basin morphology}

Gull Lake has an irregular shape and bathymetry. It is mostly elongated SW-NE, parallel to the main valley axis, with a maximum length and width of $\sim 500$ and $250 \mathrm{~m}$, respectively, for a total surface of $116 \times 10^{3} \mathrm{~m}^{2}$. There is no apparent inlet; however, the lake receives influx of snowmelt water during the spring. A small outlet, draining towards a nearby lake and the proglacial river to the north, is observable along the northern shore (Figs. 1 and 2). Based on the bathymetric map and satellite imagery, the lake can be separated into two zones: a shallow platform and a deeper basin. The shallow platform $(<2 \mathrm{~m}$ deep) occupies the periphery of the lake where it dips towards the lake center. Submerged ice-wedge polygons can be seen on this platform, as well as degraded furrows observed during the ice-free period with a submersible camera (Bouchard et al., 2015b; Video Supplement). This morphology confirms that the lake is currently evolving through lateral thermokarst encroachment. The deeper $(\sim 2-4.2 \mathrm{~m}$ deep) basin occupies the center of the lake. This area is relatively bumpy, with shallower zones that can be distinguished from a boat or on the satellite image (Fig. 2). The central basin appears asymmetrical, with maximum depths concentrated within the SW portion of the lake.

GPR surveys conducted on top of lake ice during spring (early June) 2015 provide further information about Gull Lake morphology and winter conditions (Fig. 3) (openaccess data are in Fortier et al., 2019). Lake ice thickness averages $2.1 \pm 0.1 \mathrm{~m}$ in the central basin, i.e., in areas where ice is not grounded. Lake depth is typically deeper than $3.2 \mathrm{~m}$ on average within the central basin. In contrast, mean depth is $<1 \mathrm{~m}$ within the peripheral platform, where the lake ice reaches the bottom and the freezing front penetrates lake sediments. Apart from the slightly steeper slope $\left(6^{\circ}\right.$ on average) between the shallow platform and the deeper central basin, local gradients are gentle and rarely exceed $4^{\circ}$. Finally, many strong electromagnetic reflectors are present in the ground on all GPR lines (Fig. 3). A first series of these reflectors are located underneath the lake bottom, 

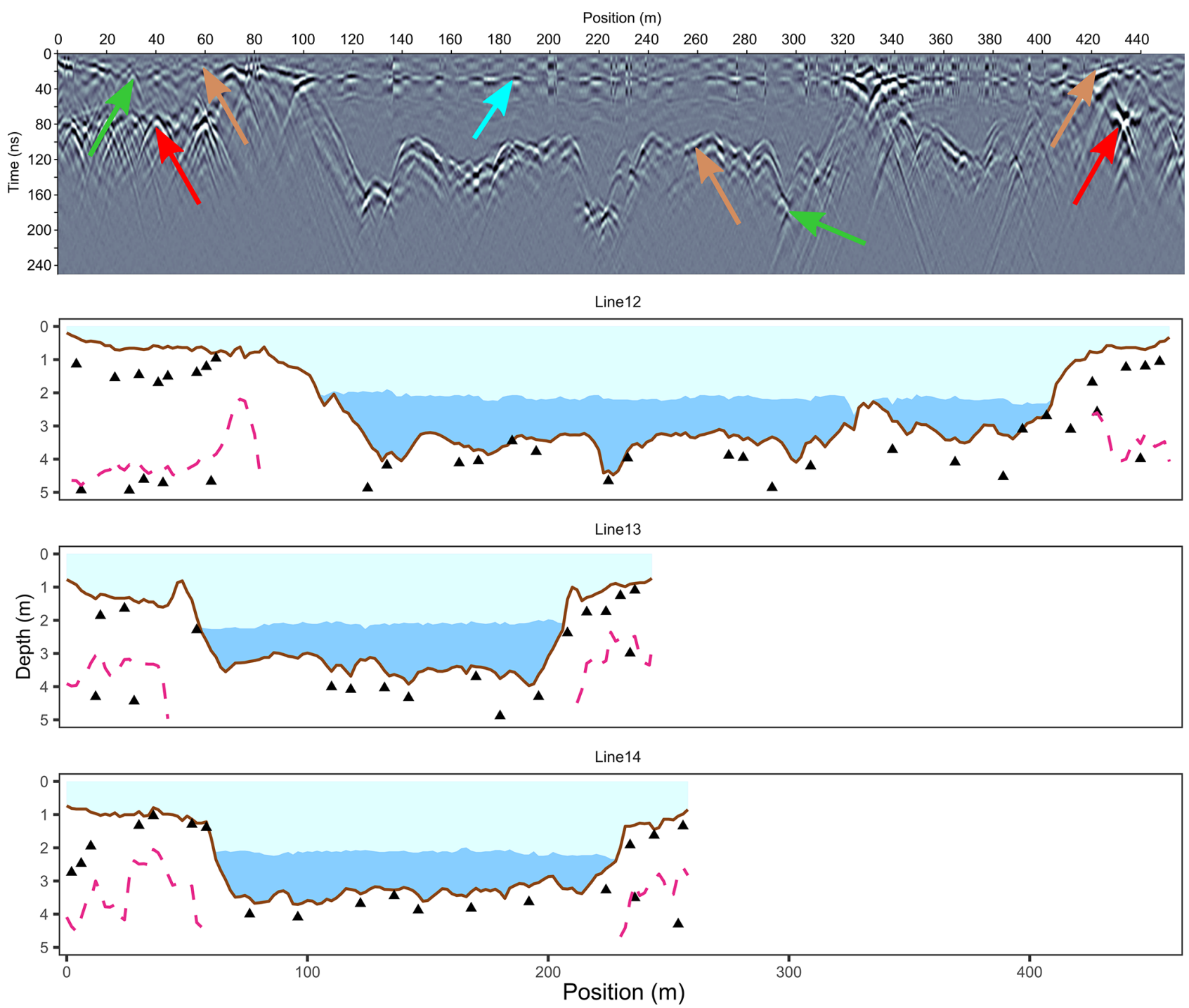

Figure 3. Interpreted GPR cross sections obtained along survey lines (see Fig. 2 for line locations). The upper figure is the raw GPR profile for line 12 , with color arrows indicating distinct reflectors such as the base of the ice cover (light blue), lake bottom (brown), former surface of ice-wedge polygon ridges and troughs (green), and the top of the glacio-fluvial sand and gravel unit (red). Lower figures are interpretations, showing the ice cover (light blue area), free water area (dark blue area), lake bottom (brown line), glacio-fluvial stratigraphic contact (pink dashed line) and identified local reflectors, pictured as triangles. Complete data (Fortier et al., 2019) are available in open-access files (see "Data availability" section).

in both shallow and deeper zones, at an average depth of $0.49 \mathrm{~m}$ under the sediment surface (range $0-1.53 \mathrm{~m}$ ). Another group of deeper reflectors are visible only under the shallow peripheral platform, at a depth of $2.6 \pm 1.4 \mathrm{~m}$. The signal velocity $\left(>0.13 \mathrm{mns}^{-1}\right)$ based on the shape of some hyperbolas suggests that they occur in frozen material. All of these reflectors are located from $\sim 5$ to $40 \mathrm{~m}$ apart (apparent distance along GPR lines). Their occurrence at shallow depths beneath the central lake basin suggests that the lake does not have a deep thawed zone (talik) as is often the case underneath deep water bodies. However, the temperature sensor installed at the bottom of the central basin indicates that surface sediments remain slightly above freezing conditions $\left(1-2^{\circ} \mathrm{C}\right)$ during nearly 9 months of the year (Supplement S3).

\subsection{Lake sediment stratigraphy}

\subsubsection{Lithostratigraphy}

Based on the description of the 2015 core, sedimentary units or zones appear as follows (Fig. 4) (Fortier and Bouchard, 2019a, b), from bottom to top (the corresponding lithostratigraphy in the 2014 core, when observed, is mentioned at the end of each paragraph): 


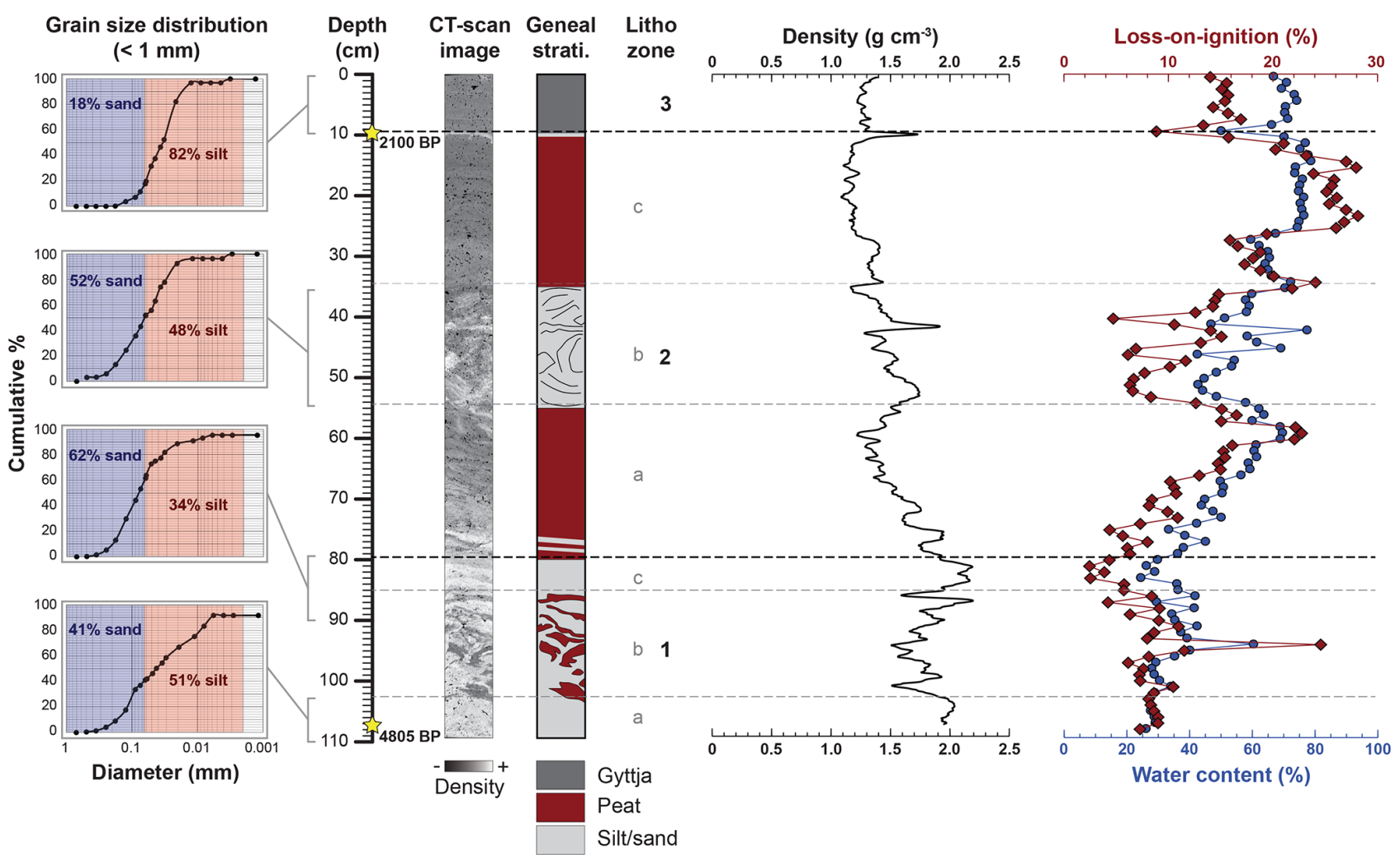

Figure 4. Lithostratigraphy of a sediment core collected in Gull Lake in June 2015. The displayed CT-scan image, as well as visual descriptions and LOI data, was used to split the sedimentary sequence into three distinct units (lithozones). Complete data (Fortier and Bouchard, 2019a, b) are available in open-access files (see "Data availability" section). CT-scan details are summarized in Supplement S1.

- Lithozone $1(109-80 \mathrm{~cm})$ is composed of mostly sand and gravel $(>50 \%)$ with scattered peat and organic debris. Subzones 1a $(109-103 \mathrm{~cm})$ and 1c (86$80 \mathrm{~cm}$ ) contain only sand and gravel, whereas subzone $1 \mathrm{~b}(103-86 \mathrm{~cm})$ contains organic debris, mostly in the form of centimeter-scale pieces of agglomerated peat. Compared to other units, lithozone 1 has a relatively high mean density $\left(\sim 2 \mathrm{~g} \mathrm{~cm}^{-3}\right)$, typical of dominantly mineral material. Water content $(20 \%-$ $40 \%)$ and LOI $(<10 \%)$ are relatively low, except for the abovementioned peat and organic debris, as shown for example by a peak at $93-94 \mathrm{~cm}$ with $60 \%$ water content and $25 \%$ LOI. Based on ${ }^{14} \mathrm{C}$ dating of one subsample $(107-108 \mathrm{~cm})$, this unit contains organic matter older than $5500 \mathrm{cal} \mathrm{BP}\left(4805{ }^{14} \mathrm{C} \mathrm{BP}\right)$ (Table 1). No equivalent was found in the shorter 2014 core.

- Lithozone $2(80-10 \mathrm{~cm}$ is composed of medium to dark brown porous peat, moderately decomposed, interbedded with millimeter-to-centimeter thick silt and sand laminations. These silt and sand laminations are generally thicker $(>1 \mathrm{~cm})$ and more present at the base of the unit than compared to the top. The average proportion of silt vs. sand in the mineral fraction is around $70 \%$ vs. $30 \%$, respectively. An intermediate subzone $2 \mathrm{~b}(55-35 \mathrm{~cm})$, richer in sand $(\sim$ $50 \%$ ) and marked by convoluted horizons, separates subzones 2a $(80-55 \mathrm{~cm})$ and $2 \mathrm{c}(35-10 \mathrm{~cm})$, which are both dominated by peat. From the bottom to the top, there is a generally decreasing trend in density from $\sim 2 \mathrm{~g} \mathrm{~cm}^{-3}$ (mostly mineral) to $\sim 1 \mathrm{~g} \mathrm{~cm}^{-3}$ (mostly organic material), with the exception of the abovementioned subzone $2 \mathrm{~b}$. Meanwhile, there is an upward increase in water content (from $20 \%$ to $>60 \%$ ) and LOI (from $<10 \%$ to $>20 \%$ ), again with the exception of subzone $2 b$. This unit was observed in the 2014 core at depths between 54 and $10 \mathrm{~cm}$.

- Lithozone $3(10-0 \mathrm{~cm})$ is composed of laminated dark organic lacustrine mud (gyttja) overlying an organicpoor silt layer $(10 \mathrm{~cm}$ deep). The relative proportion of silt vs. sand in the mineral fraction is higher $(>80 \%$ vs. $<10 \%$ ) compared to the underlying unit. With the exception of this silty mineral layer, the density is relatively low $\left(\sim 1.25 \mathrm{~g} \mathrm{~cm}^{-3}\right)$, typical of organic material. It has a high water content $(60 \%$ to $80 \%)$, similar to subzone $2 \mathrm{c}$, but a medium LOI $(\sim 15 \%)$, except for the basal silt layer $(<10 \%)$. The basal silty layer was ${ }^{14} \mathrm{C}$ dated in both 2014 and 2015 cores (Table 1), yielding an age of around $2000 \mathrm{calBP}(\sim$ 
Table 1. Radiocarbon $\left({ }^{14} \mathrm{C}\right)$ dates obtained in sediment cores collected in Gull Lake and in soil samples collected in the surrounding frozen silt-peat terrace.*

\begin{tabular}{|c|c|c|c|c|c|c|c|c|}
\hline Sample ID & Environment & Dated material & $\begin{array}{r}\text { Depth } \\
(\mathrm{cm})\end{array}$ & $\begin{array}{r}{ }^{14} \mathrm{C} \text { age } \\
(\mathrm{BP})\end{array}$ & \pm & $\begin{array}{r}\text { Calib. age } \\
\text { (cal BP) }\end{array}$ & $1 \sigma$ range & Source \\
\hline ULA-5673 & aquatic & lake sed. (bulk) & 9.25 & 2025 & 20 & 1972 & $1949-1995$ & this study \\
\hline ULA-5672 & aquatic & lake sed. (bulk) & 10.25 & 2100 & 20 & 2073 & 2042-2117 & \\
\hline ULA-5959 & aquatic & wood or plant & 107.5 & 4805 & 15 & 5505 & $5488-5588$ & \\
\hline ULA-4894 & aquatic & lake sed. (bulk) & 0.5 & 1650 & 20 & 1552 & $1533-1563$ & \\
\hline ULA-4895 & aquatic & lake sed. (bulk) & 9.5 & 2065 & 20 & 2032 & $1993-2057$ & \\
\hline ULA-4896 & aquatic & peat & 53.5 & 2635 & 20 & 2756 & $2748-2760$ & \\
\hline Beta-143333 & terrestrial & peat & 297 & 3100 & 50 & 3303 & $3245-3374$ & Ellis and Rochefort (2006) \\
\hline Beta-143337 & terrestrial & peat & 229 & 2590 & 50 & 2725 & $2541-2772$ & \\
\hline Beta-143339 & terrestrial & peat & 209 & 1660 & 40 & 1565 & $1528-1611$ & Ellis and Rochefort (2004) \\
\hline Beta-152437 & terrestrial & peat & 182 & 1470 & 40 & 1358 & $1316-1385$ & \\
\hline UL-2356 & terrestrial & wood + peat & 233 & 3670 & 110 & 4010 & $3848-4151$ & Fortier et al. (2006) \\
\hline UL-2152 & terrestrial & wood + peat & 241 & 3270 & 100 & 3506 & $3387-3607$ & \\
\hline UL-1048 & terrestrial & peat & 135 & 2210 & 120 & 2208 & $2060-2346$ & Allard (1996) \\
\hline UL-1034 & terrestrial & peat & 230 & 2510 & 90 & 2575 & $2489-2739$ & \\
\hline UL-1035 & terrestrial & peat & 250 & 2600 & 90 & 2687 & $2496-2840$ & \\
\hline UL-1025 & terrestrial & peat & 320 & 2900 & 90 & 3045 & $2894-3165$ & \\
\hline ULA-6508 & terrestrial & peat & 82 & 3045 & 15 & 3249 & $3214-3323$ & this study \\
\hline UL-2427 & terrestrial & peat & 301 & 3040 & 90 & 3228 & $3080-3362$ & \\
\hline UL-2614 & terrestrial & peat & 275 & 3350 & 90 & 3593 & $3475-3693$ & \\
\hline UL-2418 & terrestrial & wood & N/A & 3560 & 90 & 3855 & $3720-3972$ & \\
\hline UL-2584 & terrestrial & wood & N/A & 3300 & 100 & 3537 & $3403-3640$ & \\
\hline UL-2416 & terrestrial & wood + peat & 155 & 3440 & 100 & 3706 & $3586-3832$ & \\
\hline UL-2264 & terrestrial & peat & 210 & 2750 & 90 & 2869 & 2765-2943 & \\
\hline
\end{tabular}

* Other ${ }^{14} \mathrm{C}$ dates obtained near the base of the frozen silt-peat terrace in the surroundings (see text for details) are also summarized (Allard, 1996; Fortier et al., 2006; Ellis and Rochefort, 2004, 2006). Complete unpublished data (Fortier et al., 2020) are available in open-access files (see "Data availability" section).

$\left.2100{ }^{14} \mathrm{C} \mathrm{BP}\right)$. Similar sediments were observed in the 2014 core at the same depth $(10-0 \mathrm{~cm})$.

\subsubsection{Biostratigraphy}

A total of 230 diatom taxa (species or species groups) belonging to 52 genera were identified within the 60 thin sections prepared from the 2015 core (Pienitz et al., 2019). The average number of taxa for a given level was 43 , ranging from a minimum of $5(108-109 \mathrm{~cm})$ to a maximum of 60 taxa (56-58 and 18-20 cm). Among these, the 15 most frequently encountered taxa representing more than $5 \%$ in relative abundance in at least one sample were selected to show major ecological changes that occurred in the past (Fig. 5). These changes were used to delimit diatom zones (or "biozones"), which are similar to the sedimentary units (or "lithozones") described above, although exact upper and lower limits are slightly different. These major biozones are as follows from bottom to top:

- Compared to the entire core, biozone 1 (109$74 \mathrm{~cm}$ ) is characterized by a poor diversity in major taxa $(n<10)$ and in total counted taxa $(n<30$ on average per level). The diversity is especially low in subzone 1a $(109-102 \mathrm{~cm})$, with only 5 major taxa and an average of 13 counted taxa per level. Notably, the Diploneis \& Geissleria group, practically not observed anywhere else along the core, is overwhelmingly dominant within this subzone ( $>20 \%$ of relative abundance). These species are generally associated with cold, oligotrophic, organic-poor, lowconductivity and mostly alkaline $(\mathrm{pH}=\sim 8)$ waters, typical of Arctic streams and wetland headwaters (Antoniades et al., 2008; Zimmermann et al., 2010). The overlying subzones $1 \mathrm{~b}(102-86 \mathrm{~cm})$ and $1 \mathrm{c}(86-$ $74 \mathrm{~cm})$ are notably more diverse in identified taxa (average total counted taxa of 33 and 34, respectively) and dominated by aerophilous or moss-associated species (e.g., Chamaepinnularia soehrensis, Pinnularia sinistra, Diatomella balfouriana), generally living in circumneutral to slightly acidic waters, typical of high-latitude peatlands (Dermot Antoniades, personal communication, 2018; Zimmermann et al., 2010). Abundant organic debris, in the form of centimeter- 


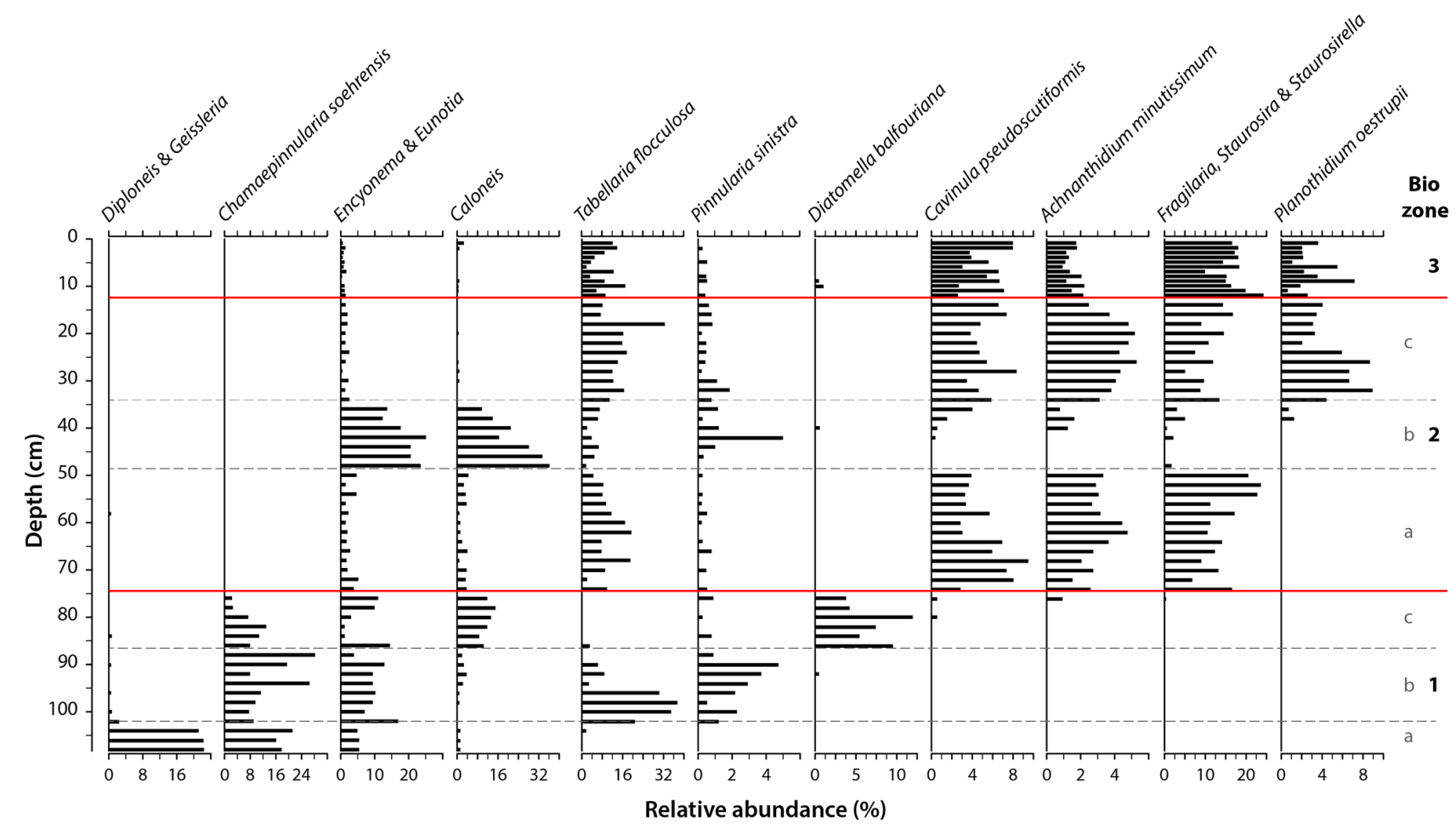

Figure 5. Biostratigraphy (fossil diatoms) of a sediment core collected in Gull Lake in June 2015. Data are displayed as relative abundance (\%) of dominant taxa, i.e., representing more than $5 \%$ in at least one level. The relative abundance scale varies by taxa. Complete data (Pienitz et al., 2019) are available in open-access files (see "Data availability" section). Plates (photographs) of the most abundant species are shown in Supplement S2.

scale pieces of peat, were indeed observed in this unit (Fig. 4).

- Biozone $2(74-12 \mathrm{~cm})$ marks an increase in the abundance of major taxa $(n>10)$, with the appearance of mostly small, benthic diatom genera (e.g., Cavinula, Achnanthidium, Fragilaria, Staurosirella) typical of shallow tundra ponds in ice-wedge polygon terrains, with cold waters and long-lasting ice cover (Antoniades et al., 2008; Ellis et al., 2008; Pienitz et al., 1995; Zimmermann et al., 2010). Total counted taxa are also much higher in this unit (nearly 50 on average per level), except in subzone $2 \mathrm{~b}(48-34 \mathrm{~cm})$ where the number of identified species per level is around 35 . This intermediate subzone corresponds to the convoluted silt and sand horizons of lithozone 2 (subzone 2b; Fig. 4) and is mostly dominated by epiphytic, moss-associated genera (Encyonema, Eunotia, Caloneis) (Antoniades et al., 2008; Ellis et al., 2008; Zimmermann et al., 2010).

- Biozone $3(12-0 \mathrm{~cm})$ is similar to the underlying biozone 2, with a slightly higher number of major taxa $(n=13)$ although a slightly lower total number of counted taxa $(n=47$ on average per level). Thin sections were more concentrated in diatom valves within this zone, especially in the upper part
$(7-0 \mathrm{~cm})$. Moreover, several taxa with a generally wide geographic distribution in lakes and wetlands and preferring high-nutrient waters (e.g., Cavinula cocconeiformis, Cymbopleura naviculiformis, Eunotia bilunaris) (Guiry and Guiry, 2019), not observed in other zones, were counted within this unit (Pienitz et al., 2019). This biozone is the equivalent of lithozone 1 (laminated lacustrine mud; Fig. 4).

\section{Discussion}

Combining geomorphological and paleolimnological observations of Gull Lake basin and bottom sediments, we can reconstruct landscape dynamics in Qarlikturvik valley and lake development during the second half of the Holocene. This evolution was, however, strongly controlled by the early Holocene deglaciation of the valley for which data from earlier studies are available. Hence, we first adopt a chronological approach in this section, covering the entire Holocene, in order to better set the stage for Gull Lake's inception. We then present a four-stage conceptual model for thermokarst lake development in syngenetic permafrost of formerly glaciated terrains. Finally, we discuss the implications of some of our results for carbon dynamics in the Arctic. 


\subsection{Holocene history of the Qarlikturvik valley and ground-ice development}

At the beginning of the Holocene, the Qarlikturvik valley was likely occupied by an inland-based glacier with a front advancing into shallow marine waters (Allard, 1996). This interpretation is based on the presence of marine shells (Mya truncata species), ${ }^{14} \mathrm{C}$ dated at $9860 \mathrm{BP}$, and found within ice-contact deposits (sands, gravels and pebbles) with lithological properties corresponding to the surrounding Precambrian and Cretaceous-Tertiary rocks. Lacelle et al. (2018) and Coulombe et al. (2019) later proposed that Laurentide ice and Bylot ice were converging in the valley. Glacial retreat was then accompanied by a marine transgression phase, associated with the deposition of silts and clays, which lasted until about $6000 \mathrm{BP}\left({ }^{14} \mathrm{C}\right.$ ages ranging from 9860 to $6100 \mathrm{BP}$ in shells at different altitudes). Such fossiliferous marine sediments were observed within pingo cores along the southern shore of the proglacial river, as upheaved and slightly deformed strata (Allard, 1996).

The second half of the Holocene was marked by the deposition of glacio-fluvial, eolian and organic sediments over the valley floor. First, following marine regression after $\sim 6 \mathrm{kyrBP}$, a glacial outwash plain probably occupied the entire valley, overlying the marine silts and clays and depositing glacio-fluvial sands and gravels (Allard, 1996; Fortier and Allard, 2004). Small streams with cold, alkaline, low-DOC and nutrient-poor waters were likely widespread within the plain, as inferred from diatoms observed at the base of the core collected in Gull Lake (Fig. 5; Antoniades et al., 2008; Zimmermann et al., 2010). The ${ }^{14} \mathrm{C}$ date of $4.8 \mathrm{kyrBP}$ at the base of the core is interpreted as reworked pieces of peat transported by glacio-fluvial waters that sedimented in channels of the outwash (Table 1). This glacio-fluvial period lasted about 2 millennia, until eolian (fine sand and silt) and organic (peat) sediments started to accumulate in the valley around $3.7 \mathrm{kyr} \mathrm{BP}$, as based on ${ }^{14} \mathrm{C}$ dating of Salix twigs and peat macrofossils (Fortier and Allard, 2004). A greater initial accumulation rate of $>2 \mathrm{~mm} \mathrm{yr}^{-1}$ occurred in this period, followed by a reduction to $<1 \mathrm{mmyr}^{-1}$ after $2.2 \mathrm{kyrBP}$ (Allard, 1996; Fortier et al., 2006). Effective organic (peat) sedimentation during this period is further supported by the presence, in the Gull Lake core, of abundant benthic and epiphytic diatom species generally preferring moss substrates typical of more acidic peatland and wetland environments (Antoniades et al., 2008; Pienitz, 2001; Zimmermann et al., 2010). These eolian and organic layers (stratified silt and peat) were gradually incorporated (syngenetically) into the permafrost as they accumulated and froze (see below).

Syngenetic permafrost and associated ground-ice development accompanied this sediment deposition and surface aggradation in the Qarlikturvik valley, forming the polygonal terrace within which numerous ponds and lakes later formed and are still visible today (Fig. 1). During the late Holocene (roughly 3500 years ago), the valley floor had completely emerged from the sea and the proglacial river running through the valley had started to cut into its own alluvial deposits. At the same time, cooler regional temperatures (the Neoglacial) resulted in slower melting of upstream glaciers, thus lower flow of the river, which enhanced the abovementioned covering of the outwash plain by eolian and organic sediments (Fortier and Allard, 2004). Neoglacial cooling was reported at numerous sites across the eastern Canadian Arctic, based on diverse paleoenvironmental indicators (summarized in Fortier et al., 2006).

Repeated thermal frost cracking during severe winters had likely started as soon as the downstream portion of the valley was exposed (i.e., around $6000 \mathrm{BP}$ ) and later affected the whole glacio-fluvial outwash plain (and the upper section of the underlying marine clay unit), resulting in the formation of a first generation of ice wedges and related polygon networks. The development of the silty peat terrace, starting at $3000-3500 \mathrm{BP}$, caused a change in thermal contraction properties of the ground, triggering the formation of a second generation of ice-wedge polygons (Fortier and Allard, 2004). As a result, ice wedges, several meters wide and 6-8 $\mathrm{m}$ deep, extend today through the sedimentary sequence, likely down to the upper section of the marine clays. These ice wedges define a complex patchwork of high-center and low-center polygons with diameters ranging from 5 to $40 \mathrm{~m}$, with the top of ice wedges coinciding with the base of the active layer (Allard, 1996). About 2000 years ago, the Gull Lake inception site was located in such a typical tundra landscape.

\subsection{Thermokarst lake evolution: a conceptual model for syngenetic permafrost in formerly glaciated terrains}

Based on our findings about the geomorphology and paleolimnology of Gull Lake's basin, we developed a conceptual model of its formation and evolution during the late Holocene, including potential future trajectories. This four-stage model is presented in Fig. 6 .

We summarized in the previous section the initial conditions before the inception of Gull Lake (stage 0), during the first half of the Holocene. At the beginning of the late Holocene, the site was characterized by a network of syngenetic ice wedges extending through frozen peat, eolian silt, glacio-fluvial sands, and likely into marine clays at depth (Fig. 6a). The silty peat unit on the terrace is about $1.5-2 \mathrm{~m}$ in thickness with a volumetric ice content exceeding $50 \%$ (Fortier and Allard 2004). Thawing of this unit under Gull Lake resulted in a $\sim 0.7 \mathrm{~m}$ layer of thawed silty peat at the bottom of the lake (Fig. 4). The underlying glacio-fluvial unit is ice poor and thus has a low subsidence potential upon thaw (Fortier and Allard, 2004). We explain the elevation gap between the maximum lake depth $(\sim 4 \mathrm{~m})$ and the potential thaw subsidence of thermokarst-susceptible 
(a) Stage 0: initial conditions (2100 BP).

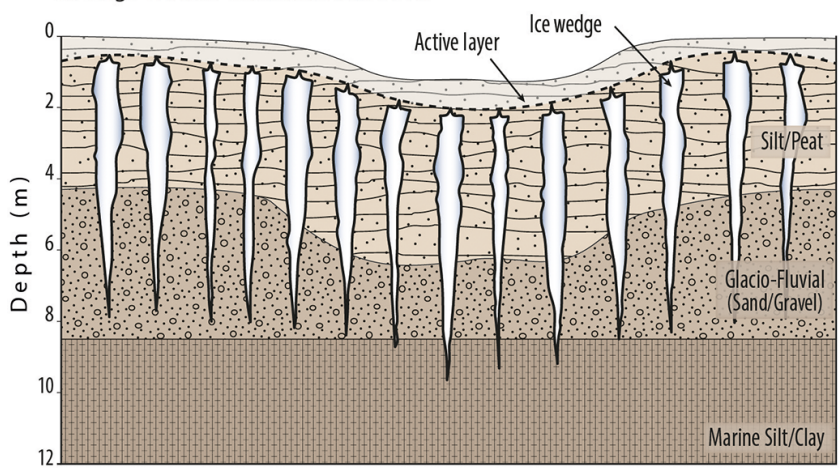

(b) Stage 1: thermokarst inception, ice-wedge melting.

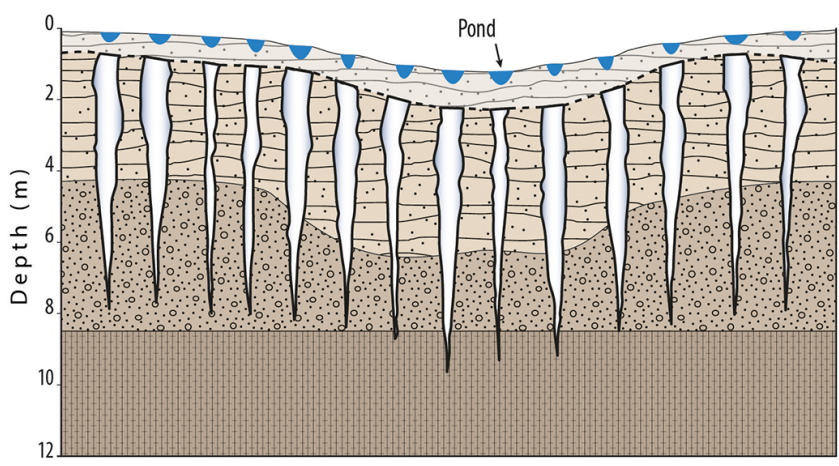

(c) Stage 2: pond coalescence, lake depth $<2 \mathrm{~m}$.

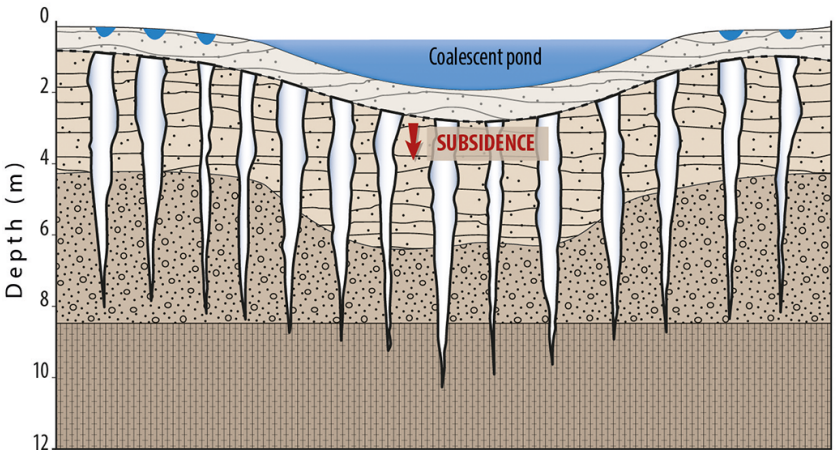

(d) Stage 3: present-day conditions - thermokarst lake development

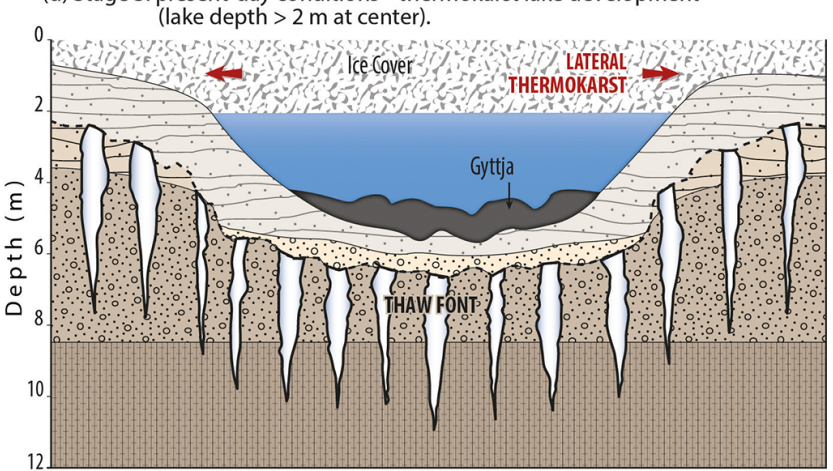

(e) Stage 4a: future development - lake sediment infilling (gyttja).

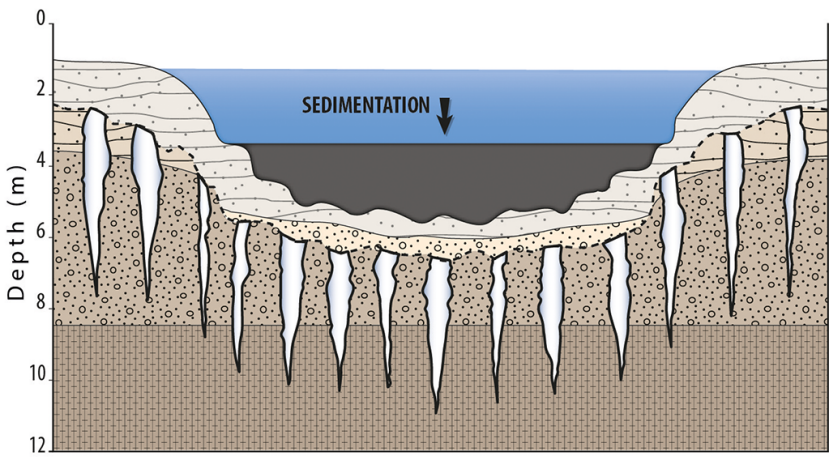

(f) Stage 4b: future development - partial lake drainage.

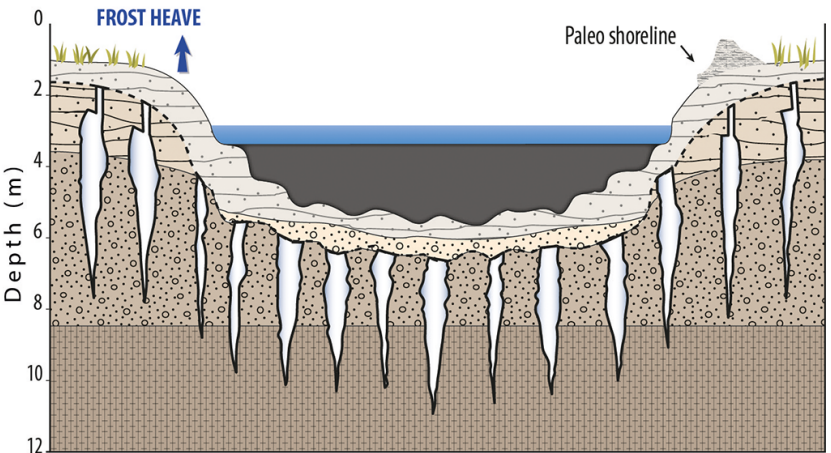

Figure 6. Four-stage conceptual model of thermokarst lake inception and evolution through the Holocene. (a) Stage 0: initial conditions with networks of ice wedges developed in frozen silt-peat and glacio-fluvial sand and gravel (and likely reaching underlying marine silts and clays). A pre-existing topographic depression of 1-2 m was collecting drifting snow and meltwater. (b) Stage 1: thermokarst inception, i.e., deepening of the active layer, melting of the top of ice wedges (triggering ice wedge truncation) and development of a hummocky surface. (c) Stage 2: thermokarst pond coalescence and formation of a small lake with a maximum depth still above maximum ice cover thickness. (d) Stage 3: thermokarst lake mature development by lateral expansion (thermal and mechanical erosion) and bottom deepening (subsidence). Lake maximum depth is now below maximum ice cover thickness, triggering the formation of a talik. (e) Stage 4a: possible future evolution by lake infilling (gyttja accumulation). (f) Stage 4b: possible future evolution by lake drainage (partial or complete) and reactivation of ice-wedge cracking and growth (i.e., no more truncation).

sediments by the presence of a pre-existing depression 1$2 \mathrm{~m}$ deeper than the surrounding polygonal network. This depression was interpreted as a channel in the glaciofluvial outwash underlying the silty peat, similar to channels observed today in the glacio-fluvial outwash in glacial valleys of Bylot Island. This depression likely collected snow and snowmelt waters, especially during years of higher precipitation and weaker winds (lower evaporation). Such conditions resulted in active layer deepening and thermokarst initiation with ice wedge melting and development of small and shallow ponds, either over the ice wedges or at their junctions (Grosse et al., 2013) (stage 1; Fig. 6b). This 
stage of the model is supported by several field studies reporting thermokarst initiation starting from the top of melting of ice wedges (e.g., Abolt et al., 2020; French, 2017; Mackay, 2000; Ward Jones et al., 2020) rather than from the center of ice-wedge polygons (where groundice content is much lower; Kanevskyi et al., 2017). This also indicates that microtopography can induce thermokarst initiation, with minimal influence from regional climate variations (Biskaborn et al., 2013). This is illustrated by Gull Lake inception (i.e., transition from terrestrial to aquatic sedimentation), which was ${ }^{14} \mathrm{C}$ dated at around $2100 \mathrm{BP}$ (Table 1 and Fig. 4), corresponding to the Neoglacial cooling period, characterized by lower-than-average air temperatures and also intervals of wetter-than-average local conditions (Fortier et al., 2006). With thermokarst and ponding, diatom communities changed from moss-associated or aerophilous (terrestrial) species to dominantly benthic or planktonic (aquatic) taxa typical of tundra ponds (Fig. 5) (Ellis et al., 2008). This mixed tundra landscape, combining terrestrial and freshwater environments, characterizes high-centered polygon networks that are observable today in the valley and elsewhere across the Arctic (e.g., Abolt et al., 2020; Kanevskiy et al., 2014; Ward Jones et al., 2020).

During autumn, heat loss from these small water bodies to the atmosphere and subsequent phase change of water to ice delayed the freezing front propagation in the underlying ground during the following winter (Kokelj and Jorgenson, 2013). Hence, this resulted in more efficient and deeper thaw during the following summer. Ponds then started to coalesce over and at the edge of ice-wedge polygons, extending the aquatic surface area over the terrestrial one (stage 2; Fig. 6c) (Shur et al., 2019). At this stage, however, the aquatic conditions likely did not last year round in these water bodies, as they were shallower than the $>2 \mathrm{~m}$ thick ice cover that forms in winter. Shallow coalescent ponds that freeze to the bottom each winter are still a common feature in the valley today.

Eventually, lateral expansion by both thermal and mechanical erosion, as well as thaw consolidation and subsidence of the silts and peats beneath water bodies, led to the formation of a lake sensu stricto, with unfrozen water beneath the ice cover throughout the winter (stage 3; Fig. 6d). Year-round aquatic conditions started to prevail, leading to the gradual accumulation of organic-rich lacustrine mud (gyttja). This is illustrated by the presence of abundant benthic and planktonic diatom species in the upper part of the analyzed core (0-10 cm; Figs. 4 and 5), typical of lacustrine ecosystems across several regions (Guiry and Guiry, 2019). However, the specific morphology of the lake, with a central deeper basin presenting relatively steep slopes surrounded by a gently sloping shallow platform, suggests that this evolution did not follow a strictly linear trend. The central basin, covered by at least $10 \mathrm{~cm}$ of lacustrine sediments at the coring site, appears notably older than the peripheral platform, where no or negligible gyttja was observed at $1 \mathrm{~m}$ depth (Video Supplement VS1). Assuming a relatively low sedimentation rate of 0.1 to $0.2 \mathrm{~mm}$ per year, typical of thermokarst lakes (Bouchard et al., 2011; Coulombe et al., 2016), the central basin was likely formed several centuries before the surrounding shallow platform.

Gull Lake's bathymetry clearly indicates that the lake bottom in the central basin is generally deeper than the maximum ice cover thickness. Hence, thermal conditions are in place for the development of a talik underneath the lake. The temperature sensor installed within surface sediments of the deepest portion of the central basin in 2014-2015 showed that it never froze, although it stayed close to $1-2{ }^{\circ} \mathrm{C}$ for 9 months of the year, i.e., from midOctober to mid-June (Supplement S3). However, an unfrozen zone could not be clearly detected along the GPR lines (Fig. 3). Moreover, the bathymetry in the central basin is notably heterogeneous, with shallow parts $(\sim 2 \mathrm{~m}$ deep) in contact with winter ice cover (GPR line 12; Fig. 3), and a deeper portion limited to the SW section of the lake (Fig. 2). The inferred talik is therefore not the typical bowl shape that underlies the whole central basin, as generally reported from other thermokarst lake basins (Morgenstern et al., 2011, and references therein), but it is closer to the configuration described by Burn (2002) for tundra lakes in the western Canadian Arctic, which have a talik under the deep central basin that is encircled by a shallow littoral terrace underlain by permafrost. A potential explanation for this heterogeneity in the deep basin bathymetry is the differential surface subsidence above ice wedges vs. above polygon centers, with the latter being tempered by the presence of fibrous peat. Based on GPR lines, the bumpy lake-bottom topography can be interpreted as the former surface of ice-wedge polygon ridges and troughs. Notably, numerous reflectors were identified along GPR lines underneath the lake bottom (at $>35 \mathrm{~cm}$ depth on average), and these reflectors were located 5 to $40 \mathrm{~m}$ apart laterally, similar to distances presently observed between ice wedges within the valley (Fig. 3) (Fortier and Allard, 2004; Fortier et al., 2019). The other (deeper) series of reflectors, found only underneath the peripheral platform (average depth of $2.6 \mathrm{~m}$ ) in frozen material, likely represent the top of the glaciofluvial unit (sand and gravel). This unit was indeed observed in the sediment core, which was collected in the deep basin in a nonfrozen state (Fig. 4). Fortier and Allard (2004) reported a similar depth for the glacio-fluvial unit, based on permafrost coring and GPR surveys on the polygonal terrace a few tens of meters from Gull Lake's northern shore.

Gull Lake is currently slowly expanding laterally by thermokarst in the syngenetic frozen silt-peat terrace, and the "thawing front" (i.e., the base of the talik) has now reached the underlying glacio-fluvial sand (Figs. 4 and 6d). The future evolution of the lake towards its final disappearance might thus include one or both of the following scenarios: (1) a gradual terrestrialization through gyttja accumulation and lake infilling (stage 4a; Fig. 6e) and (2) a rapid lateral 
drainage via shoreline breaching resulting from thermal erosion (e.g., thermo-erosion gullying, fluvial erosion) (stage $4 b$; Fig. 6f).

Lake or pond infilling causing terrestrialization has been reported from Arctic coastal Alaska (Jorgenson and Shur, 2007), subarctic eastern Canada (Payette et al., 2004) and boreal interior Alaska (Kanevskiy et al., 2014; Roach et al., 2011). We did not observe direct signs of terrestrialization at our study site. The absence of a visible inlet, as well as the relatively low concentrations of organic matter and nutrients measured at different times of the year (Bouchard et al., 2015a), might explain the slow sedimentation rate in Gull Lake. Added to current observations that (1) lake shores migrate laterally by both thermal and mechanical erosion and (2) lake peripheral platform progressively deepens by thaw subsidence, it is likely that the complete lake infilling resulting in full-scale terrestrialization might not happen in the foreseeable future. Some partial infilling might have time to occur, but natural landscape evolution is likely to result in partial lake drainage, as suggested by the presence of numerous thermo-erosion gullies in the valley and by evidence of such a partial drainage in a nearby lake (Godin and Fortier, 2012) (Fig. 7).

Partial or complete drawdown of lakes can relate to their long-term water balance in relation to regional climate (e.g., precipitation vs. evaporation) (Bouchard et al., 2013a; Riordan et al., 2006). However, thermokarst lakes can also drain catastrophically, as has been reported from several permafrost regions across the Arctic (summarized, for instance, in Grosse et al., 2013, or Kokelj and Jorgenson, 2013). The drivers for such abrupt drainage are mostly related to local geomorphology and natural landscape evolution, i.e., factors that are external to the lakes themselves. These include ice-wedge melting in the surrounding basin creating a drainage network, retrogressive development of thermo-erosion gullies towards a given lake, coastal erosion, or tapping by another lake or a river (French, 2017; Mackay, 1997). In the case of the Qarlikturvik valley in general, and Gull Lake in particular, it is likely that future evolution will involve lake drainage to a certain extent. First, networks of rapidly evolving thermo-erosion gullies, developed along melting ice-wedge networks, exist elsewhere in the valley (Fortier et al., 2007). Once initiated, these gully networks developed extremely rapidly during the first year (average erosion rates of several meters per day) and at a much slower but quasi-steady rate afterwards for the following decade (Godin and Fortier, 2012). Such processes have strong impacts on local hydrology, including snow redistribution and surface and subsurface hydrological connectivity (Godin et al., 2014). Second, field observations suggest that a nearby lake located immediately downslope of Gull Lake (informally named "Gull Lake 2" or GL-2; Fig. 1c) has partly drained in the past. This is based on the observation of former lake shores, pingo development and the absence of well-developed ice-wedge polygons in the immediate surroundings of the remnant lake (Fig. 7). Such partial drainage is likely to happen to Gull Lake in the future, affecting at least the shallow peripheral platform and leaving a residual smaller lake corresponding to the current deeper basin.

\subsection{Implications for Arctic carbon dynamics}

Several square kilometers of the Qarlikturvik valley are currently underlain by a syngenetic permafrost terrace composed of alternating mineral (silt) and organic (peat) layers with an average organic matter content of $40 \%$ (ranging from $15 \%$ to $65 \%$ ) (Fortier and Allard, 2004). Assuming that bulk organic matter contains $58 \%$ of organic carbon (Pribyl, 2010), the terrace contains more than $20 \%$ of total organic carbon (TOC). This value is roughly 1 order of magnitude higher than the $2 \%-3 \%$ TOC values generally reported from the Yedoma domain of Siberia, Alaska and NW Canada (e.g., Schirrmeister et al., 2011; Strauss et al., 2017), which can be considered a geomorphological analog. For this, we are assuming volumetric ground-ice content $(40 \%-70 \%)$ and bulk density $\left(1-1.5 \times 10^{3} \mathrm{~kg} \mathrm{~m}^{-3}\right)$ that are comparable to other circumpolar regions (Fortier et al., 2006). Since the thickness of the organic-rich permafrost terrace on Bylot Island $(3-5 \mathrm{~m})$ is roughly 1 order of magnitude lower than the average thickness of Yedoma deposits (30-50 m), specific carbon inventories in both types of landscapes can be considered more or less equivalent. However, this comparison does not take into account the lability of the organic matter, with much older parent material of a different diagenetic state in Yedoma landscapes (Mann et al., 2015; Vonk et al., 2013). Moreover, the comparison does not include any spatial considerations about the total carbon stocks: Yedoma landscapes are estimated to cover $\sim 1.0 \times 10^{6}-1.4 \times 10^{6} \mathrm{~km}^{2}$ (Strauss et al., 2017), whereas such numbers for syngenetic glaciated terrains are, to our knowledge, currently not available. There will likely be considerable regional differences in the biogeochemical response to permafrost thaw, as thaw, and the associated carbon mobilization, is influenced by local relief and parent material (geology) (Tank et al., 2020; Williams and Smith, 1989).

Nevertheless, if future climate change results in even more widespread thaw of ice-rich permafrost (Biskaborn et al., 2019), it is plausible that the thawing of $1 \mathrm{~m}$ of organic-rich frozen ground in this valley of Bylot Island could mobilize an order of magnitude more organic carbon $\left(\sim 200 \mathrm{~kg} \mathrm{Cm}^{-3}\right)$ than an equivalent layer in Yedoma landscapes (20$30 \mathrm{~kg} \mathrm{C} \mathrm{m}^{-3}$; Schirrmeister et al., 2011). These Bylot Island estimates are also much higher than those reported from the surface layer ( $0-1 \mathrm{~m})$ of comparable ice-wedge polygon terrains developed in Holocene fluvial terraces in Siberia ( $\sim 30 \mathrm{~kg} \mathrm{C} \mathrm{m}^{-3}$; Zubrzycki et al., 2013$)$ and elsewhere across the continuous permafrost zone in cryoturbated organic and mineral soils called "turbels" (ranging from $\sim 32$ to 


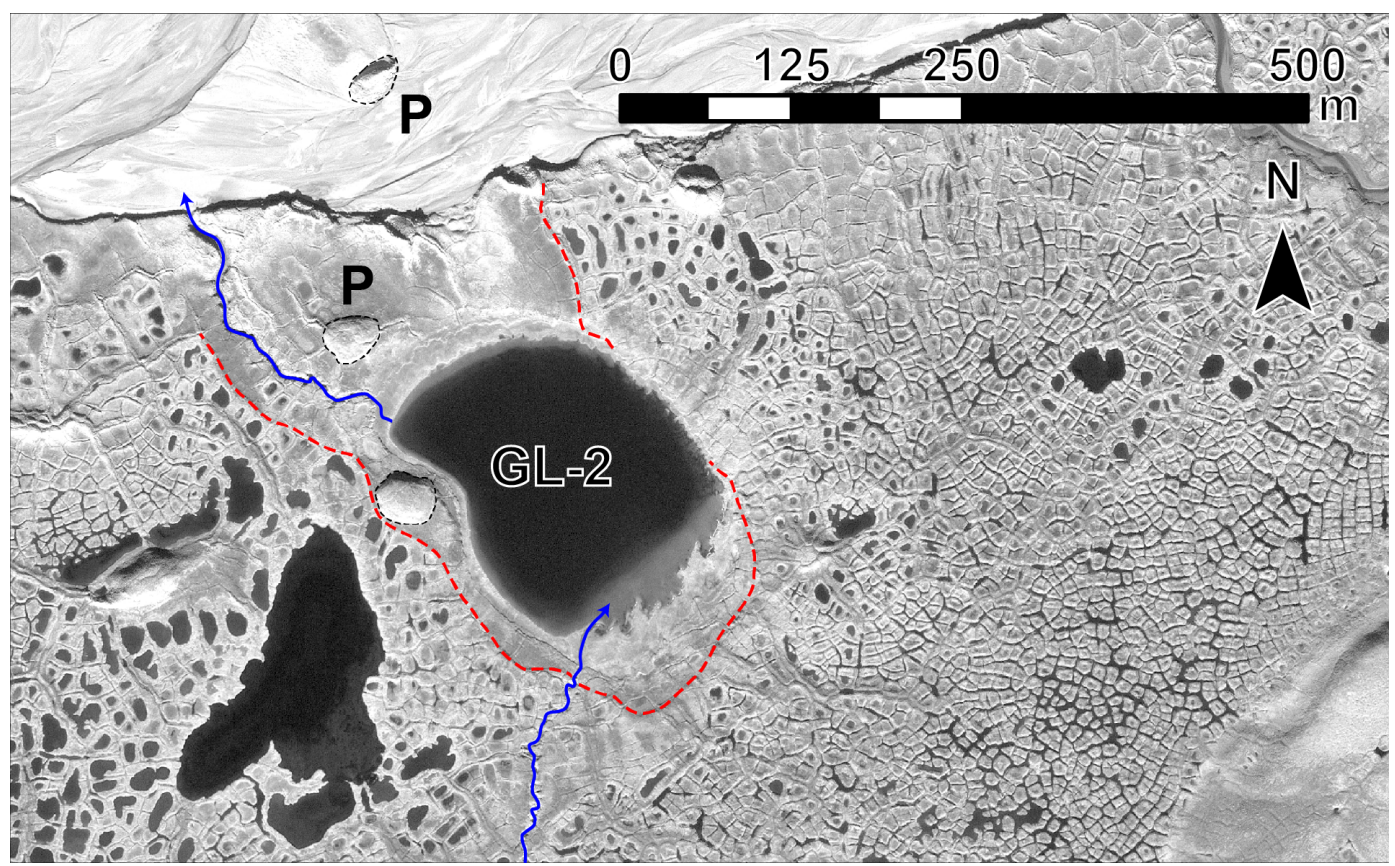

Figure 7. Signs of past partial drainage around Gull Lake 2 (GL-2). An inlet flowing from Gull Lake, located to the south, and an outlet draining towards the nearby proglacial river are shown in blue. Former lake shores are shown by the dashed red lines. Pingos are indicated by a "P". Satellite image: GeoEye-1, 18 July 2010.

$61 \mathrm{~kg} \mathrm{Cm}^{-3}$; Tarnocai et al., 2009). Therefore, the shortterm carbon feedback potential caused by GHG emissions from landscapes as presented in this study is likely much higher than from Yedoma regions and many other ice-wedge polygon sites across the Arctic. For the specific case of Gull Lake, as the base of the talik has now reached the organicpoor layer of glacio-fluvial sands, as shown by the ${ }^{14} \mathrm{C}$ maximum age of methane corresponding to the maximum age of the permafrost terrace (Bouchard et al., 2015a; Fortier and Allard, 2004), future emissions from the deep basin are likely to slow down, although lateral expansion will likely continue to promote emissions from the current peripheral platform. To propose reasonable estimates from syngenetic glaciated terrains at the global scale, we not only need to know its global extent but also the thickness and lability of the organic layer in a range of locations.

\section{Conclusions}

Combining high-resolution lake mapping (sonar and GPR), geomorphological observations and paleolimnological reconstructions (litho- and biostratigraphy) from Gull Lake on Bylot Island, we developed a conceptual model of thermokarst lake inception and evolution (past, present and future) in a syngenetic glaciated permafrost landscape of the eastern Canadian Arctic during the Holocene. The model explains multiple steps of local landscape evolution from terrestrial to freshwater environment. Paleoenvironmental reconstructions of formerly glaciated syngenetic permafrost landscapes are currently underrepresented in the thermokarst lake literature, which is dominated by Yedoma deposits (Pleistocene-age ice-rich permafrost). Moreover, this model explains the early development of thermokarst due to local topographic effects that promote top-down melting of ice wedges, resulting in thermokarst ponds over the degrading ice wedges. This is followed by the subsidence of polygon margins into the thaw ponds as the ice-rich sediments thaw and consolidate. Over time the thermokarst ponds coalesce to form a thermokarst lake.

Based on our results, we conclude that thermokarst development during the Neoglacial at our study site was not mainly driven by warmer air temperatures. We rather infer that thermokarst, in the context of the regional climate history, was mainly driven by natural landscape evolution or the complex feedback between local topography, groundice degradation, snow cover distribution and depth, and surface hydrology. The existence of a pre-existing depression (abandoned glacio-fluvial outwash channel), collecting snow and meltwater and therefore affecting ground surface temperatures, underscores the control of paleotopography on permafrost landscape evolution. Thermokarst lake development on Bylot Island during the Holocene appears as a self-enhancing process occurring within a mature landscape. This process, once initiated, proceeds regardless of variations in air temperature. This is illustrated by Gull Lake inception (around 2000 years ago), which initially 
occurred during the cooler Neoglacial climate period, underscoring the importance of precipitation and local snow distribution over temperature alone.

The valley surrounding Gull Lake is occupied by a syngenetic permafrost terrace which, although much thinner than a Yedoma ice complex (3-5 m vs. $30-50 \mathrm{~m}$, respectively), contains an order of magnitude greater amount of stored organic carbon per unit depth. Consequently, if an equivalent thickness of ice-rich permafrost thaws across the Arctic, the short-term carbon feedback potential caused by GHG emissions from this syngenetic glaciated permafrost landscape could be 10 times higher than from Yedoma soils.

Data availability. The following related datasets are available in the Nordicana D collection at Centre d'études nordiques (CEN - Centre for Northern Studies) (http://www.cen.ulaval.ca/ nordicanad/). The complete citations of each dataset appear in the reference list of this article.

Fortier et al. (2019): "Ground-penetrating radar (GPR) survey data for a thermokarst lake, Bylot Island, Nunavut, Canada", https://doi.org/10.5885/45609CE-E3573955017A4904.

Fortier and Bouchard (2019a): "Computed tomography (CT) scans of a lake sediment core, Bylot Island, Nunavut, Canada", https://doi.org/10.5885/45612CE-AB27C20EB10D4509.

Fortier and Bouchard (2019b): "Organic matter content and grain size distribution in a lake sediment core, Bylot Island, Nunavut, Canada”, https://doi.org/10.5885/45603CE-21852993EE434926.

Pienitz et al. (2019): "Fossil diatom abundance in a lake sediment core, Bylot Island, Nunavut", https://doi.org/10.5885/45600CEC0960664FE8F4038.

Fortier et al. (2020): "Radiocarbon $\left({ }^{14} \mathrm{C}\right)$ dates in terrestrial and aquatic environments, Bylot Island, Nunavut", https://doi.org/10.5885/45651CE-C6FD628F45E44578

Video supplement. The video supplement is available at https://doi.org/10.5446/43923. It shows an underwater camera video of submerged degraded ice-wedge polygons at the bottom of the peripheral shallow platform of Gull Lake, Bylot Island, Nunavut, Canada (as in Bouchard et al., 2015b). Water depth is approximately $1 \mathrm{~m}$. Footage was collected in July 2014.

Supplement. S1: computed tomography (CT) scanning of a $109 \mathrm{~cm}$ long sediment core collected in June 2015 in Gull Lake, Bylot Island, Nunavut, Canada. Methods as in Calmels and Allard (2004) (one table (Table S1) and two figures (Figs. S1-S2)). S2: plates (photographs) of the most abundant fossil diatoms found in a $109 \mathrm{~cm}$ long sediment core collected in June 2015 in Gull Lake, Bylot Island, Nunavut, Canada. Methods as in Bouchard et al. (2013b) (one figure (Fig. S3)). S3: lakewater temperatures recorded at the bottom of a thermokarst lake (2014-2015), Bylot Island, Nunavut, Canada (one figure (Fig. S4)). The supplement related to this article is available online at: https://doi.org/10.5194/tc-14-2607-2020-supplement.
Author contributions. FB, DF, RP and IL designed the methodological approach. FB, MP and VB conducted a first analysis of the data and produced the figures. DF and IL funded fieldwork sampling and analyses. FB prepared the article with contributions from all co-authors.

Competing interests. The authors declare that they have no conflict of interest.

Acknowledgements. We are grateful to the team of Gilles Gauthier (Dept. of biology, U. Laval), the Centre for Northern Studies (CEN) and the staff of the Sirmilik National Park (Parks Canada) for logistical support and access to Bylot Island. We sincerely thank Vilmantas Presskienis and Audrey Veillette for their leadership in conducting field surveys in 2015 (GPR and sediment coring) and for providing much needed help during an emergency evacuation. We also thank Jean-Philippe Tremblay and Yoan LeChasseur for fieldwork preparation assistance, Maxime Tremblay for his help in the field, Arianne Lafontaine and Andréanne Lemay for their help in the laboratory, Louise Marcoux and Sylvie St-Jacques for their assistance in drafting figures, and Stéphanie Coulombe for inspiring discussions while preparing the first draft of the manuscript. We are also very thankful to the community and the people of Mittimatalik (Pond Inlet) for access to the territory. Finally, we thank two anonymous reviewers and the editor for insightful and useful comments that greatly improved the quality of the article.

Financial support. This research has been supported by the W. Garfield Weston Foundation (W. Garfield Weston Postdoctoral Fellowship in Northern Research), ArcticNet, the Natural Sciences and Engineering Research Council of Canada (NSERC), the Polar Continental Shelf Program (PCSP) of Natural Resources Canada, the NSERC Discovery Frontiers grant "Arctic Development and Adaptation to Permafrost in Transition" (ADAPT), and the NSERC CREATE program EnviroNorth.

Review statement. This paper was edited by Peter Morse and reviewed by two anonymous referees.

\section{References}

Abnizova, A., Siemens, J., Langer, M., and Boike, J.: Small ponds with major impact: The relevance of ponds and lakes in permafrost landscapes to carbon dioxide emissions, Global Biogeochem. Cy., 26, GB2041, https://doi.org/10.1029/2011gb004237, 2012.

Abolt, C. J., Young, M. H., Atchley, A. L., Harp, D. R., and Coon, E. T.: Feedbacks between surface deformation and permafrost degradation in ice wedge polygons, Arctic Coastal Plain, Alaska, J. Geophys. Res.-Earth, 125, e2019JF005349, https://doi.org/10.1029/2019JF005349, 2020. 
Allard, M.: Geomorphological changes and permafrost dynamics: Key factors in changing arctic ecosystems. An example from Bylot Island, Nunavut, Canada, Geosci. Can., 23, 205-212, 1996.

Allard, M., Sarrazin, D., and L'Hérault, E.: Borehole and nearsurface ground temperatures in northeastern Canada, v. 1.4 (1988-2016), Nordicana, D8, https://doi.org/10.5885/45291SL34F28A9491014AFD, 2016.

Anderson, L., Edwards, M., Shapley, M. D., Finney, B. P., and Langdon, C.: Holocene Thermokarst Lake Dynamics in Northern Interior Alaska: The Interplay of Climate, Fire, and Subsurface Hydrology, Front. Earth Sci., 7, 53, https://doi.org/10.3389/feart.2019.00053, 2019.

Antoniades, D., Hamilton, P. B., Douglas, M. S. V., and Smol, J. P.: Diatoms of North America: The freshwater floras of Prince Patrick, Ellef Ringnes and northern Ellesmere Islands from the Canadian Arctic Archipelago, in: Iconographia Diatomologica, Vol. 17, A. R. G. Gantner Verlag, 649 pp., 2008.

Antoniades, D., Hamilton, P. B., Hinz, F., Douglas, M. S. V., and Smol, J. P.: Seven new species of freshwater diatoms (Bacillariophyceae) from the Canadian Arctic Archipelago, Nova Hedwigia, 88, 57-80, https://doi.org/10.1127/00295035/2009/0088-0057, 2009.

Archer, D., Eby, M., Brovkin, V., Ridgwell, A., Cao, L., Mikolajewicz, U., Caldeira, K., Matsumoto, K., Munhoven, G., Montenegro, A., and Tokos, K.: Atmospheric Lifetime of Fossil Fuel Carbon Dioxide, Annu. Rev. Earth Pl. Sc., 37, 117-134, https://doi.org/10.1146/annurev.earth.031208.100206, 2009.

ASTM: D6913-04 - Standard Test Methods for Particle-Size Distribution (Gradation) of Soils Using Sieve Analysis, ASTM International, West Conshohocken, PA, 2004.

ASTM: D7928-17 - Standard Test Method for Particle-Size Distribution (Gradation) of Fine-Grained Soils Using the Sedimentation (Hydrometer) Analysis, ASTM International, West Conshohocken, PA, 2017.

Battarbee, R., Jones, V., Flower, R., Cameron, N., Bennion, H., Carvalho, L., and Juggins, S.: Diatoms, in: Tracking Environmental Change Using Lake Sediments, Vol. 3: Terrestrial, Algal, and Siliceous Indicators, edited by: Smol, J., Birks, J., Last, W., Bradley, R., and Alverson, K., Developments in Paleoenvironmental Research, 3, Springer Netherlands, 155-202, 2001.

Biskaborn, B. K., Herzschuh, U., Bolshiyanov, D., Savelieva, L., Zibulski, R., and Diekmann, B.: Late Holocene thermokarst variability inferred from diatoms in a lake sediment record from the Lena Delta, Siberian Arctic, J. Paleolimnol., 49, 155-170, https://doi.org/10.1007/s10933-012-9650-1, 2013.

Biskaborn, B. K., Smith, S. L., Noetzli, J., et al.: Permafrost is warming at a global scale, Nat. Commun., 10, 264, https://doi.org/10.1038/s41467-018-08240-4, 2019.

Björck, S. and Wohlfarth, B.: 14C Chronostratigraphic Techniques in Paleolimnology, in: Tracking Environmental Change Using Lake Sediments, Vol. 1: Basin Analysis, Coring, and Chronological Techniques, edited by: Last, W. and Smol, J., Developments in Paleoenvironmental Research, 1, Springer Netherlands, 205-245, 2001.

Bouchard, F., Francus, P., Pienitz, R., and Laurion, I.: Sedimentology and geochemistry of thermokarst ponds in discontinuous permafrost, subarctic Quebec,
Canada, J. Geophys. Res.-Biogeo., 116, G00M04, https://doi.org/10.1029/2011JG001675, 2011.

Bouchard, F., Turner, K. W., MacDonald, L. A., Deakin, C., White, H., Farquharson, N., Medeiros, A. S., Wolfe, B. B., Hall, R. I., Pienitz, R., and Edwards, T. W. D.: Vulnerability of shallow subarctic lakes to evaporate and desiccate when snowmelt runoff is low, Geophys. Res. Lett., 40, 6112-6117, https://doi.org/10.1002/2013GL058635, 2013a.

Bouchard, F., Pienitz, R., Ortiz, J. D., Francus, P., and Laurion, I.: Palaeolimnological conditions inferred from fossil diatom assemblages and derivative spectral properties of sediments in thermokarst ponds of subarctic Quebec, Canada, Boreas, 42, 575-595, https://doi.org/10.1111/bor.12000, 2013b.

Bouchard, F., Laurion, I., Prèskienis, V., Fortier, D., Xu, X., and Whiticar, M. J.: Modern to millennium-old greenhouse gases emitted from ponds and lakes of the Eastern Canadian Arctic (Bylot Island, Nunavut), Biogeosciences, 12, 7279-7298, https://doi.org/10.5194/bg-12-7279-2015, 2015a.

Bouchard, F., Fortier, D., Paquette, M., Bégin, P. N., Vincent, W. F., and Laurion, I.: Lake bottom imagery: a simple, fast and inexpensive method for surveying shallow freshwater ecosystems of permafrost regions, Proceedings of the 7 th Canadian Permafrost Conference and the 68th Canadian Geotechnical Conference, Quebec City, Canada, 21-23 September, 2015b.

Bouchard, F., MacDonald, L. A., Turner, K. W., Thienpont, J. R., Medeiros, A. S., Biskaborn, B. K., Korosi, J., Hall, R. I., Pienitz, R., and Wolfe, B. B.: Paleolimnology of thermokarst lakes: a window into permafrost landscape evolution, Arct. Sci., 3, 91117, https://doi.org/10.1139/as-2016-0022, 2017.

Brown, J., Ferrians, O. J., Heginbottom, J. A., and Melnikov, E. S.: Circum-Arctic map of permafrost and ground-ice conditions, Revised Feb. 2001, National Snow and Ice Data Center/World Data Center for Glaciology, Boulder, Colorado, 1998.

Burn, C. R.: Tundra lakes and permafrost, Richards Island, western Arctic coast, Canada, Can. J. Earth Sci., 39, 1281-1298, https://doi.org/10.1139/e02-035, 2002.

Calmels, F. and Allard, M.: Ice segregation and gas distribution in permafrost using tomodensitometric analysis, Permafrost Periglac., 15, 367-378, https://doi.org/10.1002/ppp.508, 2004.

CEN: Climate station data from Bylot Island in Nunavut, Canada, v. 1.9 (1992-2018), available at: http://www.cen.ulaval.ca/ nordicanad/dpage.aspx?doi=45039SL-EE76C1BDAADC4890 (last access: 7 June 2019), 2018.

Cole, J. J., Caraco, N. F., Kling, G. W., and Kratz, T. K.: Carbon Dioxide Supersaturation in the Surface Waters of Lakes, Science, 265, 1568-1570, https://doi.org/10.1126/science.265.5178.1568, 1994.

Côté, M. M. and Burn, C. R.: The oriented lakes of Tuktoyaktuk Peninsula, Western Arctic Coast, Canada: a GIS-based analysis, Permafrost Periglac., 13, 61-70, https://doi.org/10.1002/ppp.407, 2002.

Coulombe, O., Bouchard, F., and Pienitz, R.: Coupling of sedimentological and limnological dynamics in subarctic thermokarst ponds in Northern Québec (Canada) on an interannual basis, Sediment. Geol., 340, 15-24, https://doi.org/10.1016/j.sedgeo.2016.01.012, 2016.

Coulombe, S., Fortier, D., Lacelle, D., Kanevskiy, M., and Shur, Y.: Origin, burial and preservation of late Pleistocene-age glacier 
ice in Arctic permafrost (Bylot Island, NU, Canada), The Cryosphere, 13, 97-111, https://doi.org/10.5194/tc-13-97-2019, 2019.

Czudek, T. and Demek, J.: Thermokarst in Siberia and its influence on the development of lowland relief, Quaternary Res., 1, 103120, https://doi.org/10.1016/0033-5894(70)90013-x, 1970.

Dean, J. F., Meisel, O. H., Martyn Rosco, M., et al.: East Siberian Arctic inland waters emit mostly contemporary carbon, Nat. Commun., 11, 1627, https://doi.org/10.1038/s41467-020-155116, 2020.

Dowdeswell, E. K., Dowdeswell, J. A., and Cawkwell, F.: On The Glaciers of Bylot Island, Nunavut, Arctic Canada, Arct. Antarct. Alpine Res., 39, 402-411, https://doi.org/10.1657/15230430(05-123)[DOWDESWELL]2.0.CO;2, 2007.

Elder, C. D., Xu, X., Walker, J., Schnell, J. L., Hinkel, K. M., Townsend-Small, A., Arp, C. D., Pohlman, J. W., Gaglioti, B. V., and Czimczik, C. I.: Greenhouse gas emissions from diverse Arctic Alaskan lakes are dominated by young carbon, Nat. Clim. Change, 8, 166-171, https://doi.org/10.1038/s41558-017-00669, 2018.

Ellis, C. J. and Rochefort, L.: Century-scale development of polygon-patterned tundra wetland, bylot island $\left(73^{\circ} \mathrm{N}, 80^{\circ} \mathrm{W}\right)$, Ecology, 85, 963-978, https://doi.org/10.1890/02-0614, 2004.

Ellis, C. J. and Rochefort, L.: Long-term sensitivity of a High Arctic wetland to Holocene climate change, J. Ecol., 94, 441454, https://doi.org/10.1111/j.1365-2745.2005.01085.x, 2006.

Ellis, C. J., Rochefort, L., Gauthier, G., and Pienitz, R.: Paleoecological Evidence for Transitions between Contrasting Landforms in a Polygon-Patterned High Arctic Wetland, Arct. Antarct. Alp. Res., 40, 624-637, https://doi.org/10.1657/15230430(07-059)[ellis]2.0.co;2, 2008.

Environment Canada: 1981-2010 Climate Normals and Averages, available at: http://climate.weather.gc.ca/ climate_normals/results_1981_2010_e.html?searchType= stnName\&txtStationName $=$ Pond+Inlet\&searchMethod $=$ contains \& txtCentralLatMin $=0 \&$ txtCentralLatSec $=0 \&$ txtCentralLongMin $=0 \&$ txtCentralLongSec $=0 \& \operatorname{stnID}=1774 \&$ dispBack=1, last access: 7 June 2019.

Fallu, M. A., Allaire, N., and Pienitz, R.: Freshwater diatoms from northern Québec and Labrador (Canada): species-environment relationships in lakes of boreal forest, forest-tundra and tundra regions, Bibliotheca Diatomologica, J. Cramer, Berlin, Stuttgart, 200 pp., 2000.

Farquharson, L., Anthony, K. W., Bigelow, N., Edwards, M., and Grosse, G.: Facies analysis of yedoma thermokarst lakes on the northern Seward Peninsula, Alaska, Sediment. Geol., 340, 2537, https://doi.org/10.1016/j.sedgeo.2016.01.002, 2016.

Fortier, D. and Allard, M.: Late Holocene syngenetic icewedge polygons development, Bylot Island, Canadian Arctic Archipelago, Can. J. Earth Sci., 41, 997-1012, https://doi.org/10.1139/e04-031, 2004.

Fortier, D. and Bouchard, F.: Computed tomography (CT) scans of a lake sediment core, Bylot Island, Nunavut, Canada, v. 1.0 (20152015), Nordicana, D54, https://doi.org/10.5885/45612CEAB27C20EB10D4509, 2019a.

Fortier, D. and Bouchard, F.: Organic matter content and grain size distribution in a lake sediment core, Bylot Island, Nunavut, Canada, v. 1.0 (2015-2015), Nordicana, D52, https://doi.org/10.5885/45603CE-21852993EE434926, 2019b.
Fortier, D., Allard, M., and Pivot, F.: A late-Holocene record of loess deposition in ice-wedge polygons reflecting wind activity and ground moisture conditions, Bylot Island, eastern Canadian Arctic, Holocene, 16, 635-646, https://doi.org/10.1191/0959683606h1960rp, 2006.

Fortier, D., Allard, M., and Shur, Y.: Observation of rapid drainage system development by thermal erosion of ice wedges on Bylot island, Canadian Arctic Archipelago, Permafrost Periglac., 18, 229-243, https://doi.org/10.1002/ppp.595, 2007.

Fortier, D., Paquette, M., and Bouchard, F.: Ground-penetrating radar (GPR) survey data for a thermokarst lake, Bylot Island, Nunavut, Canada, v. 1.0 (2015-2015), Nordicana, D53, https://doi.org/10.5885/45609CE-E3573955017A4904, 2019.

Fortier, D., Bouchard, F., Laurion, I., Pienitz, R., and Allard, M.: Radiocarbon (14C) dates in terrestrial and aquatic environments, Bylot Island, Nunavut, Nordicana, D75, https://doi.org/10.5885/45651CE-C6FD628F45E44578, 2020.

Frauenfeld, O. W., Zhang, T., Barry, R. G., and Gilichinsky, D.: Interdecadal changes in seasonal freeze and thaw depths in Russia, J. Geophys. Res., 109, D05101, https://doi.org/10.1029/2003JD004245, 2004.

French, H. M.: The periglacial environment, 4th edn., John Wiley and Sons, Chichester, UK, 515 pp., 2017.

Godin, E. and Fortier, D.: Geomorphology of a thermo-erosion gully, Bylot Island, Nunavut, Canada, Can. J. Earth Sci., 49, 979986, https://doi.org/10.1139/e2012-015, 2012.

Godin, E., Fortier, D., and Coulombe, S.: Effects of thermo-erosion gullying on hydrologic flow networks, discharge and soil loss, Environ. Res. Lett., 9, 105010, https://doi.org/10.1088/17489326/9/10/105010, 2014.

Grosse, G., Jones, B., and Arp, C.: Thermokarst Lakes, Drainage, and Drained Basins, in: Treatise on Geomorphology, edited by: Shroder, J. F., Glacial and Periglacial Geomorphology, 8, Academic Press, San Diego, CA, 325-353, 2013.

Guiry, M. D. and Guiry, G. M.: AlgaeBase, available at: http://www. algaebase.org, last access: 7 June 2019.

Heiri, O., Lotter, A. F., and Lemcke, G.: Loss on ignition as a method for estimating organic and carbonate content in sediments: reproducibility and comparability of results, J. Paleolimnol., 25, 101-110, https://doi.org/10.1023/A:1008119611481, 2001.

Hopkins, D. M.: Thaw Lakes and Thaw Sinks in the Imuruk Lake Area, Seward Peninsula, Alaska, J. Geol., 57, 119-131, 1949.

Hugelius, G., Strauss, J., Zubrzycki, S., Harden, J. W., Schuur, E. A. G., Ping, C.-L., Schirrmeister, L., Grosse, G., Michaelson, G. J., Koven, C. D., O’Donnell, J. A., Elberling, B., Mishra, U., Camill, P., Yu, Z., Palmtag, J., and Kuhry, P.: Estimated stocks of circumpolar permafrost carbon with quantified uncertainty ranges and identified data gaps, Biogeosciences, 11, 6573-6593, https://doi.org/10.5194/bg-11-6573-2014, 2014.

Jones, B. M. and Arp, C. D.: Observing a Catastrophic Thermokarst Lake Drainage in Northern Alaska, Permafrost Periglac., 26, 119-128, https://doi.org/10.1002/ppp.1842, 2015.

Jorgenson, M. T. and Shur, Y.: Evolution of lakes and basins in northern Alaska and discussion of the thaw lake cycle, J. Geophys. Res.-Earth, 112, F02S17, https://doi.org/10.1029/2006jf000531, 2007. 
Juggins, S.: C2 version 1.7.6. Software for ecological and palaeoecological data analysis and visualisation, Univ. of Newcastle, Newcastle upon Tyne, 2014.

Kanevskiy, M., Jorgenson, T., Shur, Y., O’Donnell, J. A., Harden, J. W., Zhuang, Q., and Fortier, D.: Cryostratigraphy and Permafrost Evolution in the Lacustrine Lowlands of West-Central Alaska, Permafrost Periglac., 25, 14-34, https://doi.org/10.1002/ppp.1800, 2014.

Kanevskyi, M., Shur, Y., Jorgenson, T. Beown, D. R. N., Moskalenko, N., Brown, J., Walker, D. A., Raynolds, M. K., Bucchorn, M.: Degradation and stabilization of ice wedges: Implications for assessing risk of thermokarst in northern Alaska, Geomorphology, 297, 20-42, https://doi.org/10.1016/j.geomorph.2017.09.001, 2017.

Klassen, R. A.: Quaternary Geology and Glacial History of Bylot Island, Northwest Territories, Memoir 429, no. 429, Geological Survey of Canada, Ottawa, 1993.

Kokelj, S. V. and Jorgenson, M. T.: Advances in Thermokarst Research, Permafrost Periglac., 24, 108-119, https://doi.org/10.1002/ppp.1779, 2013.

Krammer, K.: The genus Pinnularia, in: Diatoms of Europe Diatoms of the European inland waters and comparable habitats, vol. 1, edited by: Lange-Bertalot, H., A. R. G. Gantner Verlag K. G., Ruggel, 2000.

Krammer, K.: Cymbella, in: Diatoms of Europe - Diatoms of the European inland waters and comparable habitats, vol. 3, edited by: Lange-Bertalot, H., A. R. G. Gantner Verlag K. G., Ruggel, 2002.

Krammer, K. and Lange-Bertalot, H.: Bacillariophyceae 1. Teil: Naviculaceae, in: Süßwasserflora von Mitteleuropa, edited by: Ettl, H., Gerloff, J., Heynig, H., and Mollenhauer, D., Gustav Fischer Verlag, Stuttgart, New York, 1986.

Krammer, K. and Lange-Bertalot, H.: Bacillariophyceae 2. Teil: Bacillariaceae, Epithemiaceae, Surirellaceae, in: Süßwasserflora von Mitteleuropa, edited by: Ettl, H., Gerloff, J., Heynig, H., and Mollenhauer, D., Gustav Fischer Verlag, Stuttgart, New York, 1988.

Krammer, K. and Lange-Bertalot, H.: Bacillariophyceae 3. Teil: Centrales, Fragilariaceae, Eunotiaceae, in: Süßwasserflora von Mitteleuropa, edited by: Ettl, H., Gerloff, J., Heynig, H., and Mollenhauer, D., Gustav Fischer Verlag, Stuttgart, New York, 1991a.

Krammer, K. and Lange-Bertalot, H.: Bacillariophyceae 4. Teil: Achnanthaceae, Kritische Ergänzungen zu Navicula (Lineolatae) und Gomphonema, in: Süßwasserflora von Mitteleuropa, edited by: Ettl, H., Gerloff, J., Heynig, H., and Mollenhauer, D., Gustav Fischer Verlag, Stuttgart, New York, 1991b.

Lacelle, D., Fisher, D. A., Coulombe, S., Fortier, D., and Frappier, R.: Buried remnants of the Laurentide Ice Sheet and connections to its surface elevation, Sci. Rep., 8, 13286-13286, https://doi.org/10.1038/s41598-018-31166-2, 2018.

Lantz, T. C. and Turner, K. W.: Changes in lake area in response to thermokarst processes and climate in Old Crow Flats, Yukon, J. Geophys. Res.-Biogeo., 120, 513-524, https://doi.org/10.1002/2014JG002744, 2015.

Laurion, I., Vincent, W. F., MacIntyre, S., Retamal, L., Dupont, C., Francus, P., and Pienitz, R.: Variability in greenhouse gas emissions from permafrost thaw ponds, Limnol. Oceanogr., 55, 115-133, https://doi.org/10.4319/lo.2010.55.1.0115, 2010.
Lavoie, I., Hamilton, P. B., Campeau, S., Grenier, M., and Dillon, P. J.: Guide d'identification des diatomées des rivières de l'Est du Canada, Presses de l'Université du Québec, Québec, 241 pp., 2008.

Lenz, J., Wetterich, S., Jones, B. M., Meyer, H., Bobrov, A., and Grosse, G.: Evidence of multiple thermokarst lake generations from an 11800 -year-old permafrost core on the northern Seward Peninsula, Alaska, Boreas, 45, 584-603, https://doi.org/10.1111/bor.12186, 2016.

Mackay, J. R.: A full-scale field experiment (1978-1995) on the growth of permafrost by means of lake drainage, western Arctic coast: a discussion of the method and some results, Can. J. Earth Sci., 34, 17-33, https://doi.org/10.1139/e17-002, 1997.

Mackay, J. R.: Thermally induced movements in ice-wedge polygons, western arctic coast: a long-term study, Geogr. Phys. Quatern., 54, 41-68, https://doi.org/10.7202/004846ar, 2000.

Mackay, J. R. and Burn, C. R.: The first 20 years (1978-1979 to 1998-1999) of ice-wedge growth at the Illisarvik experimental drained lake site, western Arctic coast, Canada, Can. J. Earth Sci., 39, 95-111, https://doi.org/10.1139/e01-048, 2002.

Mann, P. J., Eglinton, T. I., McIntyre, C. P., Zimov, N., Davydova, A., Vonk, J. E., Holmes, R. M., and Spencer, R. G. M.: Utilization of ancient permafrost carbon in headwaters of Arctic fluvial networks, Nat. Commun., 6, 7856, https://doi.org/10.1038/ncomms8856, 2015.

Matveev, A., Laurion, I., and Vincent, W. F.: Methane and carbon dioxide emissions from thermokarst lakes on mineral soils, Arct Sci., 4, 584-604, https://doi.org/10.1139/as-2017-0047, 2018.

Moorman, B. J.: Ground-Penetrating Radar Applications in Paleolimnology, Vol. 1: Basin Analysis, Coring, and Chronological Techniques, in: Tracking Environmental Change Using Lake Sediments, edited by: Smol, J. P. and Last, W. M., Springer Netherlands, 23-47, 2001.

Morgenstern, A., Grosse, G., Günther, F., Fedorova, I., and Schirrmeister, L.: Spatial analyses of thermokarst lakes and basins in Yedoma landscapes of the Lena Delta, The Cryosphere, 5, 849-867, https://doi.org/10.5194/tc-5-849-2011, 2011.

Morse, P. D., Burn, C. R., and Kokelj, S. V.: Influence of snow on near-surface ground temperatures in upland and alluvial environments of the outer Mackenzie Delta, Northwest Territories, Can. J. Earth Sci., 49, 895-913, https://doi.org/10.1139/e2012-012, 2012.

Muster, S., Roth, K., Langer, M., Lange, S., Cresto Aleina, F., Bartsch, A., Morgenstern, A., Grosse, G., Jones, B., Sannel, A. B. K., Sjöberg, Y., Günther, F., Andresen, C., Veremeeva, A., Lindgren, P. R., Bouchard, F., Lara, M. J., Fortier, D., Charbonneau, S., Virtanen, T. A., Hugelius, G., Palmtag, J., Siewert, M. B., Riley, W. J., Koven, C. D., and Boike, J.: PeRL: a circum-Arctic Permafrost Region Pond and Lake database, Earth Syst. Sci. Data, 9, 317-348, https://doi.org/10.5194/essd-9-3172017, 2017.

Paltan, H., Dash, J., and Edwards, M.: A refined mapping of Arctic lakes using Landsat imagery, Int. J. Remote Sens., 36, 59705982, https://doi.org/10.1080/01431161.2015.1110263, 2015.

Paquette, M., Fortier, D., Mueller, D. R., Sarrazin, D., and Vincent, W. F.: Rapid disappearance of perennial ice on Canada's most northern lake, Geophys. Res. Lett., 42, 14331440, https://doi.org/10.1002/2014GL062960, 2015. 
Payette, S., Delwaide, A., Caccianiga, M., and Beauchemin, M.: Accelerated thawing of subarctic peatland permafrost over the last 50 years, Geophys. Res. Lett., 31, L18208, https://doi.org/10.1029/2004GL020358, 2004.

Pienitz, R.: Analyse des microrestes végétaux: diatomées, in: Écologie des tourbières du Québec-Labrador, edited by: Payette, S. and Rochefort, L., Les Presses de l'Université Laval, Québec, 311-326, 2001.

Pienitz, R., Bouchard, F., and Boucher, V.: Fossil diatom abundance in a lake sediment core, Bylot Island, Nunavut, Canada, v. 1.0 (2015-2015), Nordicana, D51, https://doi.org/10.5885/45600CE-C0960664FE8F4038, 2019.

Pienitz, R., Doran, P. T., and Lamoureux, S. F.: Origin and geomorphology of lakes in the polar regions, in: Polar Lakes and Rivers: Limnology of Arctic and Antarctic Aquatic Ecosystems, edited by: Vincent, W. and Laybourn-Parry, J., Oxford University Press, Oxford, UK, 25-41, 2008.

Pienitz, R., Smol, J. P., and Birks, H. J. B.: Assessment of freshwater diatoms as quantitative indicators of past climatic change in the Yukon and Northwest Territories, Canada, J. Paleolimnol., 13, 21-49, https://doi.org/10.1007/bf00678109, 1995.

Pribyl, D. W.: A critical review of the conventional SOC to SOM conversion factor, Geoderma, 156, 75-83, https://doi.org/10.1016/j.geoderma.2010.02.003, 2010.

Reimer, P. J., Bard, E., Bayliss, A., Beck, J. W., Blackwell, P. G., Ramsey, C. B., Buck, C. E., Cheng, H., Edwards, R. L., Friedrich, M., Grootes, P. M., Guilderson, T. P., Haflidason, H., Hajdas, I., Hatté, C., Heaton, T. J., Hoffmann, D. L., Hogg, A. G., Hughen, K. A., Kaiser, K. F., Kromer, B., Manning, S. W., Niu, M., Reimer, R. W., Richards, D. A., Scott, E. M., Southon, J. R., Staff, R. A., Turney, C. S. M., and van der Plicht, J.: IntCal13 and Marine13 Radiocarbon Age Calibration Curves 0-50000 Years cal BP, Radiocarbon, 55, 1869-1887, https://doi.org/10.2458/azu_js_rc.55.16947, 2013.

Riordan, B., Verbyla, D., and McGuire, A. D.: Shrinking ponds in subarctic Alaska based on 1950-2002 remotely sensed images, J. Geophys. Res.-Biogeo., 111, G04002, https://doi.org/10.1029/2005jg000150, 2006.

Roach, J., Griffith, B., Verbyla, D., and Jones, J.: Mechanisms influencing changes in lake area in Alaskan boreal forest, Glob. Change Biol., 17, 2567-2583, https://doi.org/10.1111/j.13652486.2011.02446.x, 2011.

Schirrmeister, L., Kunitsky, V., Grosse, G., Wetterich, S., Meyer, H., Schwamborn, G., Babiy, O., Derevyagin, A., and Siegert, C.: Sedimentary characteristics and origin of the Late Pleistocene Ice Complex on north-east Siberian Arctic coastal lowlands and islands - A review, Quatern. Int., 241, 3-25, https://doi.org/10.1016/j.quaint.2010.04.004, 2011.

Schuur, E. A. G., McGuire, A. D., Schadel, C., Grosse, G., Harden, J. W., Hayes, D. J., Hugelius, G., Koven, C. D., Kuhry, P., Lawrence, D. M., Natali, S. M., Olefeldt, D., Romanovsky, V. E., Schaefer, K., Turetsky, M. R., Treat, C. C., and Vonk, J. E.: Climate change and the permafrost carbon feedback, Nature, 520, 171-179, https://doi.org/10.1038/nature14338, 2015.

Serikova, S., Pokrovsky, O. S., Laudon, H., Krickov, I. V., Lim, A. G., Manasypov, R. M., and Karlsson, J.: High carbon emissions from thermokarst lakes of Western Siberia, Nat. Commun., 10, 1552, https://doi.org/10.1038/s41467-019-09592-1, 2019.
Shur, Y., Fortier, D., Jorgenson, T., Kanevskyi, M., Jones, B. M., Ward-Jones, M. K.: Self-organization of ice wedge systems during their formation and degradation, American Geophysical Union Fall Meeting, San Francisco, 9-13 December, C13E1359, 2019.

Smith, L. C., Sheng, Y. W., and MacDonald, G. M.: A first pan-Arctic assessment of the influence of glaciation, permafrost, topography and peatlands on Northern Hemisphere lake distribution, Permafrost Periglac., 18, 201-208, https://doi.org/10.1002/ppp.581, 2007.

Smith, S. and Burgess, M. M.: Ground Temperature Database for Northern Canada, Geological Survey of Canada, Ottawa, Open File Report 3954, 28, 2000.

Strauss, J., Schirrmeister, L., Grosse, G., Fortier, D., Hugelius, G., Knoblauch, C., Romanovsky, V., Schädel, C., Schneider von Deimling, T., Schuur, E. A. G., Shmelev, D., Ulrich, M., and Veremeeva, A.: Deep Yedoma permafrost: A synthesis of depositional characteristics and carbon vulnerability, Earth-Sci. Rev., 172, 75-86, https://doi.org/10.1016/j.earscirev.2017.07.007, 2017.

Stuiver, M., Reimer, P. J., and Reimer, R. W.: CALIB 7.1, available at: http://calib.org, last access: 23 July 2019.

Tarnocai, C., Canadell, J. G., Schuur, E. A. G., Kuhry, P., Mazhitova, G., and Zimov, S.: Soil organic carbon pools in the northern circumpolar permafrost region, Global Biogeochem. Cy., 23, GB2023, https://doi.org/10.1029/2008GB003327, 2009.

Tank, S. E., Vonk, J. E., Walvoord, M. A., McClelland, J. W., Laurion, I., and Abbott, B. W.: Landscape matters: Predicting the biogeochemical effects of permafrost thaw on aquatic networks with a state of factor approach, Permafrost Periglac., 31, 358370, https://doi.org/10.1002/ppp.2057, 2020.

Turner, K. W., Wolfe, B. B., and Edwards, T. W. D.: Characterizing the role of hydrological processes on lake water balances in the Old Crow Flats, Yukon Territory, Canada, using water isotope tracers, J. Hydrol., 386, 103-117, https://doi.org/10.1016/j.jhydrol.2010.03.012, 2010.

van Everdingen, R.: Multi-language glossary of permafrost and related ground-ice terms, National Snow and Ice Data Center/World Data Center for Glaciology, Boulder (CO), 1998 (revised 2005).

Verpoorter, C., Kutser, T., Seekell, D. A., and Tranvik, L. J.: A global inventory of lakes based on high-resolution satellite imagery, Geophys. Res. Lett., 41, 6396-6402, https://doi.org/10.1002/2014GL060641, 2014.

Vonk, J. E., Mann, P. J., Davydov, S., Davydova, A., Spencer, R. G. M., Schade, J., Sobczak, W. V., Zimov, N., Zimov, S., Bulygina, E., Eglinton, T. I., and Holmes, R. M.: High biolability of ancient permafrost carbon upon thaw, Geophys. Res. Lett., 40, 2689 2693, https://doi.org/10.1002/grl.50348, 2013.

Walter, K. M., Edwards, M. E., Grosse, G., Zimov, S. A., and Chapin, F. S.: Thermokarst lakes as a source of atmospheric $\mathrm{CH}_{4}$ during the last deglaciation, Science, 318, 633-636, https://doi.org/10.1126/science.1142924, 2007.

Ward Jones, M. K., Pollard, W. H., and Amyot, F.: Impacts of degrading ice-wedges on ground temperatures in a high Arctic polar desert system, J. Geophys. Res.-Earth, 125, e2019JF005173, https://doi.org/10.1029/2019JF005173, 2020.

Wik, M., Varner, R. K., Anthony, K. W., MacIntyre, S., and Bastviken, D.: Climate-sensitive northern lakes and ponds are 
critical components of methane release, Nat. Geosci., 9, 99, https://doi.org/10.1038/ngeo2578, 2016.

Williams, P. and Smith, M.: The Frozen Earth: Fundamentals of Geocryology (Studies in Polar Research), Cambridge University Press, Cambridge (UK), 306 pp., https://doi.org/10.1017/CBO9780511564437, 1989.

Yoshikawa, K. and Hinzman, L. D.: Shrinking thermokarst ponds and groundwater dynamics in discontinuous permafrost near council, Alaska, Permafrost Periglac., 14, 151-160, https://doi.org/10.1002/ppp.451, 2003.

You, Y., Yu, Q., Pan, X., Wang, X., and Guo, L.: Geophysical Imaging of Permafrost and Talik Configuration Beneath a Thermokarst Lake, Permafrost Periglac., 28, 470-476, https://doi.org/10.1002/ppp.1938, 2017.
Zimmermann, C., Poulin, M., and Pienitz, R.: Diatoms of North America: The Pliocene-Pleistocene freshwater flora of Bylot Island, Nunavut, Canadian High Arctic, Iconographia Diatomologica, Vol. 21, A. R. G. Gantner Verlag, 2010.

Zubrzycki, S., Kutzbach, L., Grosse, G., Desyatkin, A., and Pfeiffer, E.-M.: Organic carbon and total nitrogen stocks in soils of the Lena River Delta, Biogeosciences, 10, 3507-3524, https://doi.org/10.5194/bg-10-3507-2013, 2013. 